\title{
How to Make a Heart Valve: From Embryonic Development to Bioengineering of Living Valve Substitutes
}

\author{
Donal MacGrogan ${ }^{1}$, Guillermo Luxán ${ }^{1}$, Anita Driessen-Mol ${ }^{2}$, Carlijn Bouten², \\ Frank Baaijens ${ }^{2}$, and José Luis de la Pompa ${ }^{1}$ \\ ${ }^{1}$ Program of Cardiovascular Developmental Biology, Department of Cardiovascular Development \\ and Repair, Centro Nacional de Investigaciones Cardiovasculares (CNIC), 28029 Madrid, Spain \\ ${ }^{2}$ Biomedical Engineering/Eindhoven University of Technology, 5600 MB Eindhoven, \\ The Netherlands \\ Correspondence: jlpompa@cnic.es
}

\begin{abstract}
Cardiac valve disease is a significant cause of ill health and death worldwide, and valve replacement remains one of the most common cardiac interventions in high-income economies. Despite major advances in surgical treatment, long-term therapy remains inadequate because none of the current valve substitutes have the potential for remodeling, regeneration, and growth of native structures. Valve development is coordinated by a complex interplay of signaling pathways and environmental cues that cause disease when perturbed. Cardiac valves develop from endocardial cushions that become populated by valve precursor mesenchymeformed byan epithelial-mesenchymal transition (EMT). The mesenchymal precursors, subsequently, undergo directed growth, characterized by cellular compartmentalization and layering of a structured extracellular matrix (ECM). Knowledge gained from research into the development of cardiac valves is driving exploration into valve biomechanics and tissue engineering directed at creating novel valve substitutes endowed with native form and function.
\end{abstract}

$\mathrm{C}$ ardiac valves maintain unidirectional blood flow during the cardiac cycle. As the heart contracts and relaxes, passive opening and closing of the valves, caused by a transvalvular pressure gradient, results in alternate blood flow from the atria to the ventricles and from the ventricles to the great vessels (Fig. 1A) (Yoganathan et al. 2000; Sacks and Yoganathan 2007). When the ventricles contract, the inlet or atrioventricular $(\mathrm{AV})$ valves (the tricuspid and mitral valves) prevent backflow from the ventricles to the atria; and when they relax, the outlet or semilunar (SL) valves (the pulmonary and aortic valves) prevent reverse flow from the arteries to the ventricles. Valve malfunction occurs when the valve fails to open properly (stenosis) or does not shut completely (regurgitation).

Heart valve disease, which primarily affects the aortic and miral valves, is a health-care problem of epidemic proportions because of the in-

Editors: Margaret Buckingham, Christine L. Mummery, and Kenneth R. Chien

Additional Perspectives on The Biology of Heart Disease available at www.perspectivesinmedicine.org

Copyright (C) 2014 Cold Spring Harbor Laboratory Press; all rights reserved; doi: 10.1101/cshperspect.a013912

Cite this article as Cold Spring Harb Perspect Med 2014;4:a013912 
D. MacGrogan et al.

A

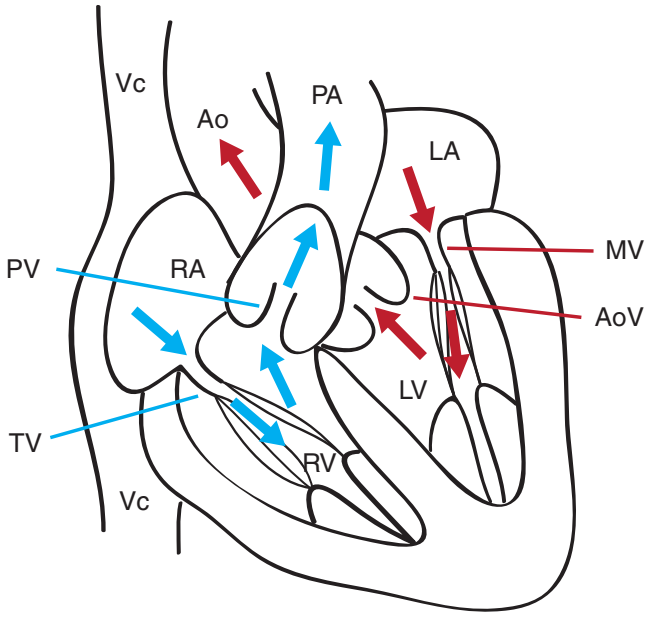

B

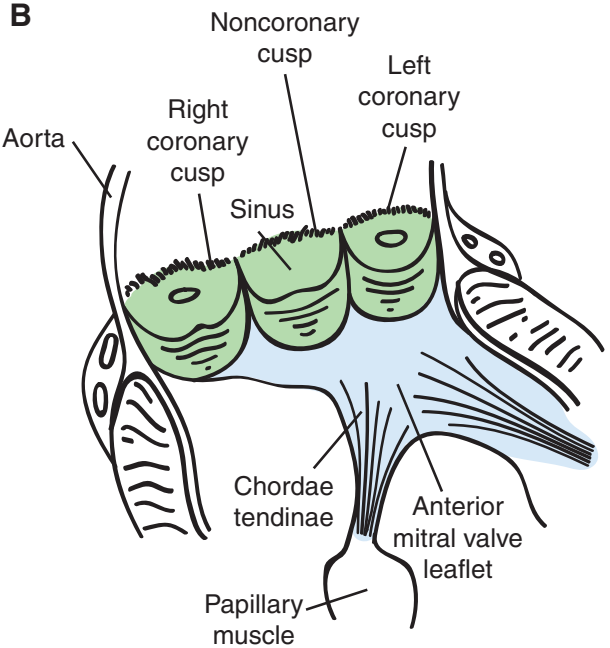

C

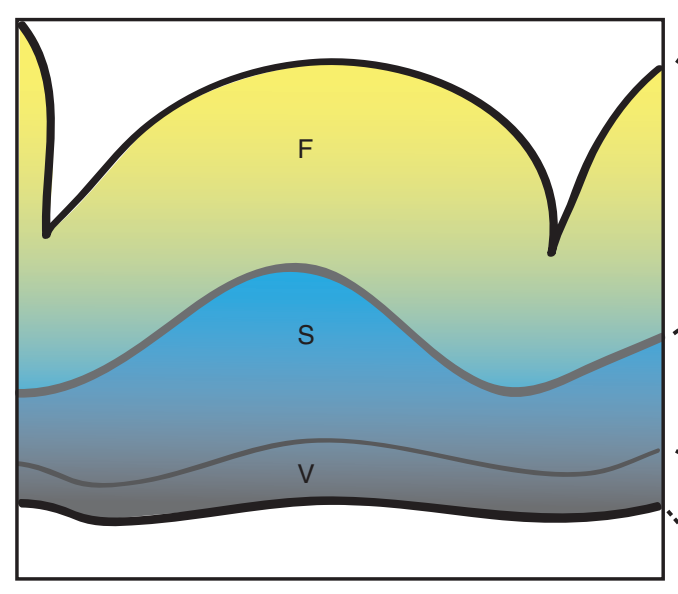

D

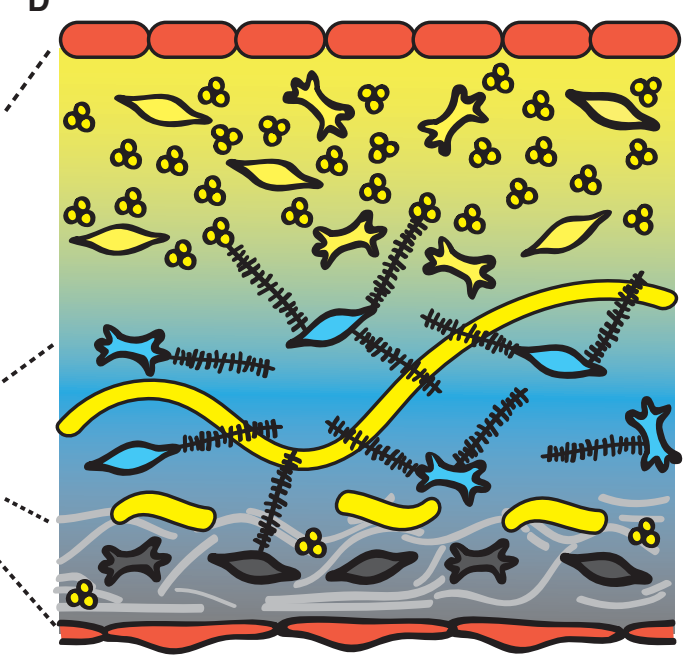

Figure 1. Heart valve structure and function. (A) Oxygen-depleted blood (blue) enters the heart from the vena cava $(\mathrm{Vc})$ through the right atrium (RA) and transits via the tricuspid valve (TV) into the right ventricle (RV). From there, it passes through the pulmonary valve $(\mathrm{PV})$ and reaches the lungs via the pulmonary artery (PA). Oxygen-rich blood from the lungs (red) enters the left atrium (LA) and empties into the left ventricle (LV) by passing through the mitral valve (MV). From the LV, the blood is pumped through the aortic valve (AoV) to the aorta (Ao), and from there it distributes to the rest of the body. (B) Scheme of a longitudinally opened aortic root, showing the close relation between aortic (green) and mitral (blue) valves in situ. The cusps are attached to the annulus fibrosus, a fibroelastic structure entrapping the valves (not shown). The free edge of the AoV leaflets is anchored to the LV wall by papillary muscles via chordae tendinae. $(C)$ Artist rendition of a Movat's pentachrome staining of a cross section of the AoV cusp. (D) Depiction of the detailed architecture. The monolayer of endothelium (red) lining the valves has a cuboidal appearance on the arterial side and a flattened appearance of the ventricular side. Fibroblasts, smooth muscle, and myofibrolasts are interspersed in the different layers. Collagen (yellow) is densely packed and fibrillar and circumferential in the fibrosa (F), loose in the spongiosa (S), and multidirectional in the ventricularis (V). Proteoglycans (black) predominate in the spongiosa, and interact with cells and collagen. Radial elastin (light gray) predominates in the ventricularis. 
creasing burden of elderly patients with degenerative heart valve disease and a growing population of young adults with congenital heart disease, involving complex valve anomalies. The gold standard treatment for advanced heart valve disease is surgical replacement, but none of the currently available mechanical and biological heart valve substitutes are ideal solutions. Thus, patients fitted with mechanical valves face the burden of lifelong treatment with anticoagulants, whereas patients with biological valves face the prospect of reoperation because of the limited durability of biological valve substitutes (Schoen and Levy 2005). Tissue engineering seeks to overcome these drawbacks by exploiting living cells to develop a living valve replacement that has the capacity to remodel in response to functional demand and repair inflicted damage. In principle, the living tissue-engineered heart valve (TEHV) could have the capacity to grow, but once it has matured, it might achieve the same functional and durability properties as the native valve. The superiority of a living heart valve replacement is underscored by the outstanding results achieved using living autografts compared with nonliving homografts for aortic root replacement (El-Hamamsy et al. 2010).

Translating knowledge gained from studying the mechanisms that drive valve development to engineering living valve replacements is an ongoing challenge for biomedical engineers. This article describes the anatomy and structure of native adult cardiac valves, summarizes how the endocardial cushions (ECs) form by epithelial-mesenchyme transition (EMT) and extracardiac mesenchyme contribution, and reviews the processes of valve morphogenesis and the ensuing cellular and matrix remodeling that give rise to the mature cusps and leaflets. The article closes by outlining how this knowledge is applied in state-of-the-art of tissue-engineering approaches to generate functional and long-lasting cardiac valve replacements.

\section{CARDIAC VALVE ANATOMY}

Cardiac valves have a complex anatomy (Yoganathan et al. 2000; Sacks and Yoganathan 2007; Schoen 2008). The central component of each valve consists of three leaflets, except the mitral valve (MV), which has only two leaflets (Fig. 1B). The AV valves are attached to the annulus fibrosus, a fibroelastic tissue that encircles the AV canal and outflow tract (OFT) and provides structural support to the valves while also separating the ventricular and atrial myocardium. The free edges of the $\mathrm{AV}$ valves are tethered to the base of the ventricular walls by tendon-like cords, called chordae tendinae, via papillary muscles (Fig. 1B). This "subvalvular apparatus" maintains the AV leaflets within the ventricular chamber, preventing their prolapse into the atria during valve closure or ventricular contraction. Systolic billowing of one or both leaflets, as seen in MV prolapse, can be caused by myxomatous degeneration, rupture of the chordae tendinae, or, in cases of infarction or ventricular hypertrophy, displacement of the papillary muscles (Guy and Hill 2012). The SL valves do not require a supporting apparatus. Instead, the aortic valve $(\mathrm{AoV})$ cusps are self-supporting and attach to crown-shaped arterial roots via the annulus fibrosus, whereas the pulmonary valve (PV) cusps insert primarily through a freestanding muscular sleeve called the right ventricular infindibulum. AV (or PV) insufficency is caused by improper coaptation of the valve cusps and results in the movement of blood down its pressure gradient back into the ventricles (Prodromo et al. 2012).

\section{STRUCTURAL BASIS OF VALVE FUNCTION}

The composition and distribution of specialized valvular connective tissue types is essential for maintaining normal valve function throughout life (Hinton and Yutzey 2011). The design of replacements that faithfully reproduce native valves depends on elucidating the role played by the extracellular matrix (ECM) in valve development and maintenance.

\section{THE ECM}

Traditionally, the cardiac valves have been described as having a trilamellar architecture, which incorporates cellular and ECM components (Fig. 1C) (Latif et al. 2005; Schoen 2008). The layer closest to the sinus side (or atrial side 
D. MacGrogan et al.

for AV valves), called fibrosa, is composed of densely packed fibrillar collagens whose circumferential orientation provides tensile strength when the valve is closed. The expression of collagens (mainly type I, and some type II and V) is not restricted to the outflow layer, but suffuses all the valve strata to form a network of thin fibrils, enmeshing and interacting with the other ECM and cellular components. (Fig. 1D) The intervening spongiosa is composed primarily of glycosamino- and proteoglycans and serves as a buffer zone for the bending and stretching imposed by leaflet opening and closing (Fig. 1C,D). Glycoaminoglycans are found throughout the valves and consist of hyaluronic acid (HA), a nonproteoglycan polysaccharide, chondroitin sulfates 4 and 6, and decorin (Latif et al. 2005). Proteoglycans are necessary for the stable assembly of the ECM and functional cel1-ECM interactions, whereas decorin and biglycan interact specifically with type I collagen fibrils, modulating the kinetics of fibril formation and the distance between adjacent collagen fibrils. Facing blood flow is a thin ventricularis (or atrialis in the AV valves) composed of elastin and collagen, which provides elasticity through mostly radially oriented elastic fibers (Fig. 1C,D).

\section{ECM Functions}

The valve ECM does not merely afford a physical support for cellular growth, it is also a biologically active structure that provides cells with instructional cues and signals (mechanical and humoral), which determine many cellular functions. Valve cells bind to the ECM either through focal adhesions, which connect to actin filaments in the cell, or hemidesmosomes, which connect to intermediate filaments, such as keratin. These cell-matrix interactions are regulated by integrins, which interact with the ECM through associations of their extracellular domains with glycosaminoglycans and laminins bound to fibronectin. This sequence initiates intracellular signaling pathways and associations with the cellular cytoskeleton via adaptor molecules, such as actin. Moreover, collagen-binding glycans, including HA and decorin, can regulate cell-matrix interactions and growth-factor signal output by sequestering growth factors and receptors, thereby regulating the release and diffusion of signaling effectors (reviewed in Latif et al. 2005).

\section{CARDIAC VALVE CELL TYPES}

Cardiac valve cells sense the local environment through poorly characterized mechanotransduction pathways. These pathways mediate connective tissue repair through the synthesis, degradation, and remodeling of the ECM, enabling the cells to maintain homeostasis through continuous adaptation to dynamic strain and shear stress states (Fig. 1C).

\section{Valvular Endothelial Cells}

Cardiac valve cusps and leaflets are covered by a monolayer of endothelial cells (valvular endothelial cells [VECs]), which are continuous with the endocardium and endothelium of the aortic and pulmonary arteries (Tao et al. 2012). The VEC population regulates multiple aspects of valve physiology, including platelet aggregation, inflammation, myofibroblast contraction and migration, and valve mechanics (Butcher and Markwald 2007; Sacks and Yoganathan 2007; Schoen 2008; El-Hamamsy et al. 2009). The importance of VECs for these processes is underscored by the fact that VEC dysfunction is strongly associated with valvular dysfunction (Leask et al. 2003). In response to injury or disease, VECs can replenish the pool of valve interstitial cells through a process of EMT (Bischoff and Aikawa 2011). Valve cusp endothelium is morphologically different from vascular wall endothelium and responds differently to fluid shear stress. Vascular endothelial cells realign to be parallel with flow in response to cyclic shear stress, whereas VECs always align perpendicularly to flow, regardless of the underlying matrix orientation (Butcher and Nerem 2004). Transcriptional profiling indicates that, although mechanical stress activates a common set of genes in the endothelia of valves and vessels, each cell type also activates its own unique gene expression program when exposed to the 
same mechanical environment (Butcher and Nerem 2006). VECs, too, have different phenotypes on the ventricular and arterial sides of the AoV, being flattened on the ventricular side, but having a cuboidal appearance on the arterial side (Maron and Hutchins 1974; Bischoff and Aikawa 2011). Gene expression analysis of the AoV comparing the disease-prone aortic side to the disease-free ventricular side revealed a procalcific gene program on the aortic side, suggested by lower expression of several inhibitors of calcification, coexisting with relatively antioxidative and anti-inflammatory expression profiles (Simmons et al. 2005). The existence of varying shear stress conditions on the opposite sides of the valve cusps may account for this regional heterogeneity and point to endothelial mechanotransduction as an important contributing factor to the development and progression of calcific valve stenosis (Weinberg et al. 2010).

\section{Valvular Interstitial Cells}

Cardiac valves are populated by a heterogeneous collection of smooth muscle cells, fibroblasts, and myofibroblasts interspersed between the ECM layers (Fig. 1C) (Taylor et al. 2003; Liu and Gotlieb 2007). Valvular interstitial cells (VICs) are highly plastic and can reversibly transition from fibroblast to smooth muscle-like cells (Rabkin-Aikawa et al. 2004). Fibroblasts produce and secrete most of the surrounding ECM, whereas smooth muscle cells secrete matrix metalloproteases (MMPs) and tissue inhibitors of MMPs, which, respectively, promote and inhibit ECM breakdown in remodeling valves (Rabkin et al. 2001; Soini et al. 2001; Fondard et al. 2005). Interstitial cells are highly responsive to biochemical and biophysical stimuli produced by their surroundings (Sacks and Yoganathan 2007; Chen and Simmons 2011; Warnock et al. 2011). They are normally quiescent, but can become contractile and migratory in remodeling or diseased valves (Rabkin et al. 2001; Rabkin-Aikawa et al. 2004). Native valves undergo passive loading regimes, including flexures and planar tension forces, and VICs respond by altering their stiffness through in- creased $\alpha$-smooth muscle actin expression and biosynthesis and remodeling of ECM components (Weston and Yoganathan 2001; Gupta and Grande-Allen 2006; Ku et al. 2006; Merryman et al. 2006; Balachandran et al. 2009; Gupta et al. 2009b). The degree of matrix stiffness, in turn, modulates VIC response to biochemical cues (Yip et al. 2009). AoV interstitial cells respond differently to shear stress and mechanical loading, depending on whether endothelial cells are present (Butcher and Nerem 2006; Sacks and Yoganathan 2007; El-Hamamsy et al. 2009). Thus, VECs contribute to valve homeostasis and ECM remodeling by regulating the VIC phenotype, and this regulation is enhanced by shear flow. Pulsatile hemodynamic shear stress affects VICs through the transduction of mechanical forces by VECs or through bulk matrix shear stress, which induces tensile forces within the valve matrix. Additionally, these forces might be transmitted via the release of vasoactive substances (serotonin, nitric oxide, etc.) or cytokines, which have been shown to alter the contractile and biosynthetic properties of VICs in vitro (Liu and Gotlieb 2007).

\section{OVERVIEW OF EARLY CARDIAC DEVELOPMENT}

At embryonic day (E) 7.0 in the gastrulating mouse embryo, precardiac precursor cells derived from the epiblast emerge from the primitive streak and move forward bilaterally into the lateral plate mesoderm to form the cardiac crescent (Fig. 2A). At this stage, cardiac precursors are restricted to the splanchic (visceral) mesoderm, having become specified by signals emanating from the endoderm and surrounding tissues (Harvey 2002; Brand 2003; Abu-Issa and Kirby 2007). By E8.0, folding of mesodermal layers from both sides of the embryo at the ventral midline results in formation of the linear heart tube, consisting of an inner endocardium and outer myocardium. The heart tube is derived from the first heart field (FHF) of the splanchic mesoderm and contributes cardiac precursors to the atria, atrioventricular canal (AVC), and left ventricle (Buckingham et al. 2005). At E9.0, the tubular heart bends right- 
D. MacGrogan et al.

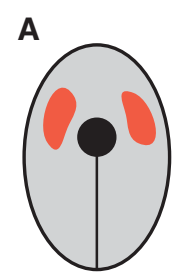

E7.0

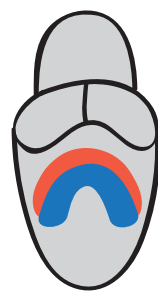

E7.5

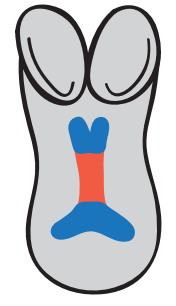

E8.0

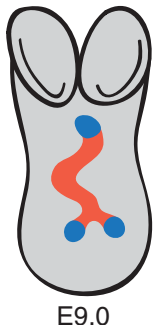

E9.0
B

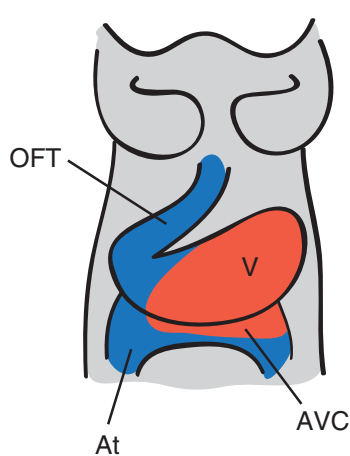

C

E9.5

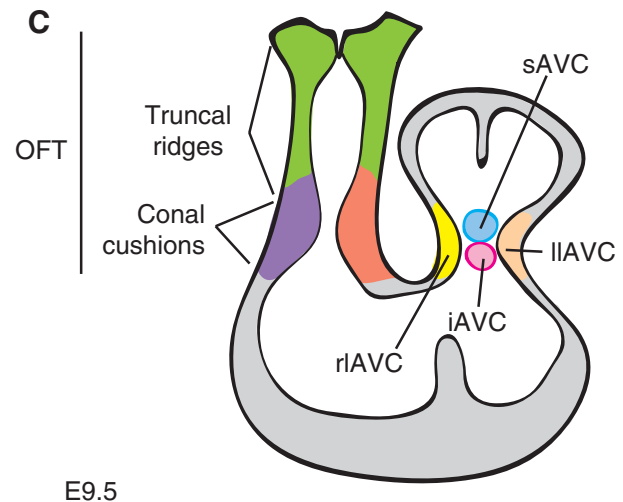

Figure 2. Early stages of heart development. (A) Ventral views of the developing mouse embryo. At E7.0, cardiac progenitors (red) have reached the head folds and, by E7.5, two cardiac lineages can be distinguished: the first heart field (FHF) (red) and the second heart field (SHF) (blue). At E8.0, the FHF progenitors merge to form the heart tube, which elongates at arterial and venous poles by the addition of progenitor cells from the second heart field (SHF). Between E8.0 and E9.0, the heart tube undergoes rightward looping. (B) Ventral view of the E9.5 heart, which consists of four anatomically distinct regions: atrium (At), atrioventricular canal (AVC), ventricle (V), and the outflow tract (OFT). (C) Longitudinal section depicting the prevalvular ECs. Two elongated cushions can be seen in the OFT, consisting of proximal (conal cushions, purple) and distal (truncal ridges, green) sections. The AVC has four cushions: right lateral (rlAVC), left lateral (llAVC), superior (sAVC), and inferior (iAVC). (Figure created from data adapted from Snarr et al. 2008.)

ward to reorient its original anterior portion along the left-right axis of the embryo and, by doing so, brings the atrial region into a position posterior to the common ventricle (Manner 2009). Concomitantly, the heart expands and elongates at both poles by the addition of progenitor cells coming from a second pool of pharyngeal mesoderm cells called the second heart field (SHF) (Kelly and Buckingham 2002; Dyer and Kirby 2009). At the arterial pole, the newly added cells give rise to the OFT, right ventricle, and interventricular septum (Zaffran et al. 2004; Verzi et al. 2005), whereas, at the venous pole, they contribute to the atria and atrial septum through the AV septal complex (Fig. 2B) (Snarr et al. 2008).

\section{PATTERNING OF CARDIAC VALVE TERRITORY AND EMT}

Cardiac valves formation in chicken, mice, and humans is restricted to the AVC and OFT regions of the looping heart (Fig. 2B,C). The ECs, that is, the primordia of the valves and septae, are formed in these regions by tissue patterning and EMT. These morphogenetic programs are stepwise processes governed by mechanical forces produced in the hemodynamic environment (Egorova et al. 2011; Riem Vis et al. 2011). Perturbation of the EMT process may lead to hypo- or hypercellurized cushions and, subsequently, to a spectrum of cardiovascular anomalies affecting the valves, septae, and 
heart chambers. Endocardial tissue patterning is achieved by establishing developmental domains permissive for valve formation (de la Pompa and Epstein 2012). Specification of the heart-valve-forming region requires signaling from myocardial bone morphogenetic protein 2 (Bmp2) to activate $T b \times 2$ (Yamada et al. 2000; $\mathrm{Ma}$ et al. 2005). Outside this territory, cardiogenic signals activate expression of Tbx20, which drives expression of Hey 1 and Hey 2 and represses Tbx2 (Singh et al. 2005; Stennard et al. 2005; Kokubo et al. 2007). Tbx20 and Hey1,2, thus, restrict Bmp2 and Tbx2 to valve territory. In the endocardium, Notch1 represses Bmp2 via Hey1, Hey2, and HeyL rendering AVC endocardial endothelium competent to form heartvalve mesenchyme (Luna-Zurita et al. 2010).

The first signs of EC formation occur at E9.5 when swellings of proteoglycan-rich ECM secreted by the myocardium appear at the AV and OFT junctions (Eisenberg and Markwald 1995; Person et al. 2005). Over the following day, a subset of endocardial cells lining the AV and OFT cushions undergo EMT (Eisenberg and Markwald 1995; Armstrong and Bischoff 2004; Person et al. 2005). These transforming cells hypertrophy, lose apicobasal polarity, extend filipodia, and migrate into the cardiac jelly (Eisenberg and Markwald 1995; Person et al. 2005). Snaill and Slug/Snail2 are crucial transcription factors for EMT because they down-regulate the expression of vascular endothelial cadherin, an adhesion molecule that maintains intercellular junctions in endothelial tissue (Romano and Runyan 1999; Timmerman et al. 2004; Niessen et al. 2008). Interestingly, in zebrafish, AV valve leaflets form directly through a process of invagination, during which the endocardium does not transform, but instead remains as a single sheet of cells (Scherz et al. 2008).

The signaling pathways that control endocardial EMT have been recently reviewed in depth (Lim and Thiery 2012; von Gise and Pu 2012). EMT induction is regulated by a network integrating Bmp, transforming growth factor (TGF) $-\beta$, and Notch signaling (Yamagishi et al. 2009; Lencinas et al. 2011; de la Pompa and Epstein 2012; Kruithof et al. 2012). Downstream from TGF- $\beta$, $\beta$-catenin acts in the AVC endocardium to pro- mote the acquisition of a mesenchymal phenotype (Gessert and Kuhl 2010). The precise spatiotemporal pattern and levels of vascular endothelial growth factor (VEGF) expression are critical for both the onset and resolution of EMT (Dor et al. 2001; Chang et al. 2004; Stankunas et al. 2010). Nfatc1 is required downstream from VEGF to regulate the extent of EMT and sustain endocardial proliferation during EMT and post-EMT valve elongation (Chang et al. 2004; Wu et al. 2011; Lin et al. 2012). The ErbB/SHP-2/NF-1/Ras signaling axis promotes mesenchymal migration into the cardiac jelly and proliferation and expansion of cushion mesenchyme (Yutzey et al. 2005; Iwamoto and Mekada 2006; Sanchez-Soria and Camenisch 2010).

The ECM is a critical regulator of EMT (Schroeder et al. 2003; Lockhart et al. 2011). Disruption of hyaluronan synthase-2 (Has2) abrogates normal cardiac morphogenesis and EMT mediated by HA (Camenisch et al. 2002). High molecular weight $\mathrm{HA}$ interacts with and activates ErbB2-ErbB3 receptors, initially, to promote EMT and, subsequently, in its depolymerized form to limit the extent of endocardial cell delamination and transformation (Camenisch et al. 2002; Rodgers et al. 2006). Moreover, a similar cardiac phenotype to the HA-deficient embryos occurs in zebrafish harboring a mutated uridine $5^{\prime}$-diphosphate (UDP)-glucose dehydrogenase (ugdh) gene ( jekyll mutant). This enzyme produces UDP-glucuronate, which is necessary for Has2 synthesis of HA, suggesting that Ugdh may function in valve formation through its requirement for HA synthesis (Walsh and Stainier 2001).

\section{CARDIAC VALVE MORPHOGENESIS}

Valvular morphogenesis is intimately tied to developmental processes that lead to heartchamber septation and connection to pulmonary and systemic circuitries. Multiple types of progenitor cells, originating from both inand outside the heart orchestrate valve morphogenesis through highly conserved signaling networks. Once again, mistiming or malfunction of the unfolding events cause valvuloseptal de- 
D. MacGrogan et al.

fects in patients with congenital heart disease and in experimental animal models (Srivastava 2006; Joziasse et al. 2008; Lin et al. 2012).

\section{Prefusion of Mesenchyme Structures}

By E10.5, EMT subsides in the AVC. The major (inferior and superior) AV cushions constitute the bulk of mesenchyme occupying the AVC lumen (Figs. 2B and 3A). Smaller lateral AV cushions start to develop at this stage (Fig. 3A) (Wessels and Sedmera 2003; Snarr et al. 2008). The major cushions take part in the formation of the AV mesenchymal complex and contribute to the formation of the aortic leaflet of the MV and septal leaflet of the tricuspid valve (TV) (Snarr et al. 2008). The lateral AV cushions do not fuse, nor do they participate in AV complex formation. Instead, the right cushion gives rise to the anterosuperior and -posterior leaflets of the TV, whereas the left cushion gives rise to the mural leaflet of the MV (Fig. 3A,B) (Snarr et al. 2008).

By E11.5, the OFT is occupied by spiraling and elongated mesenchymal cushions, referred to as septal and parietal ridges, and two less prominent intercalating ridges (Snarr et al. 2008). The boundary between the proximal conal and distal truncal cushions is marked by the outer curvature of the OFT (i.e., the cono-truncal curvature) and determines the site for SL valve formation (Fig. 2B) (Lin et al. 2012). By E12.5, the fused larger cushions and nonfused Immunocytochemistry (ICC) have given rise to the three arterial valve cusps for each SL valve (Fig. 3A,B). The major cushions participate in forming the aortico-pulmonary septum and contribute to the $\mathrm{R}-\mathrm{L}$ coronary cusps of the AoV and $\mathrm{R}-\mathrm{L}$ cusps of the PV. The intercalating cushions do not fuse; instead, the right lateral cushion gives rise to the noncoronary (NC) cusp of the AoV, whereas the left lateral cushion gives rise to the anterior leaflet of the PV. Eventually, the coronary arteries connect to the AoV sinuses immediately proximal to the $\mathrm{R}-\mathrm{L}$ cusp precursors.

\section{Lineage Tracing of Valve Tissues}

\section{Atrioventricular Valves}

Labeling of endothelial and endocardial lineages using the Tie2-Cre; ROSA26R mouse line shows that the early mesenchyme forming the major cushions is derived almost entirely from endocardial EMT (Rivera-Feliciano et al. 2006; Snarr et al. 2008). $\beta$-galactosidase ( $\beta$-gal) staining is detected in the AV fibrous continuity, valve leaflets, and the chordae tendinae at later gestational stages and postnatally, consistent with these structures being derived from the endocardium (de Lange et al. 2004; Lincoln et al. 2004).

Contributions to $\mathrm{AV}$ valve formation by the epicardium and cardiac neural crest also require an EMT process (Fig. 4B) (Lim and Thiery 2012; von Gise and $\mathrm{Pu}$ 2012). After undergoing EMT, epicardium-derived cells (EPDCs) give rise to the subepicardial mesenchyme and, subsequently, yield fibroblasts in the myocardial wall and smooth muscle cells of the media in coronary arteries (Lie-Venema et al. 2007; von Gise and Pu 2012). Quail-chick chimera analysis indicates that EPDCs populate the mesenchyme of developing $\mathrm{AV}$ valves and contribute to the fibrous heart skeleton (Fig. 4B) (Gittenberger-de Groot et al. 1998; Snarr et al. 2008). EPDC fate analysis using the mouse inducible Wt1-Cre $e^{E R T 2}$; ROSA26 Cre reporter line shows an important contribution to the $\mathrm{AV}$ sulcus and annulus fibrosus, a fibrous continuity that, in addition to separating atrial and ventricular myocardium, supports the mature valve leaflets (Zhou et al. 2010). At around E12.0, EPDCs migrate through the $\mathrm{AV}$ junction to populate the AV cushions. Using the Wt1/IRES/GFPCre; ROSA26 Cre reporter line, $\beta$-gal positive cells can be readily detected in the remodeled leaflets derived from the postfusion lateral cushions, but there is little contribution to the major AV cushions (Wessels et al. 2012). In the mural MV and TV leaflets, the EPDCs eventually replace the endocardially derived cells to make up most of the mesenchyme. Remarkably, these same leaflets are often implicated in congenital and acquired valve abnormalities, including Ebstein's anomaly, AV valve insufficiency or prolapse, and mitral/tricuspid stenosis (Fig. 4B) (Snarr et al. 2008).

A third source of $\mathrm{AV}$ leaflet mesenchyme is a population of cranial neural crest cells (CNCCs) (Fig. 4B). Beginning at E9.5, after undergoing 
How to Make a Heart Valve

A
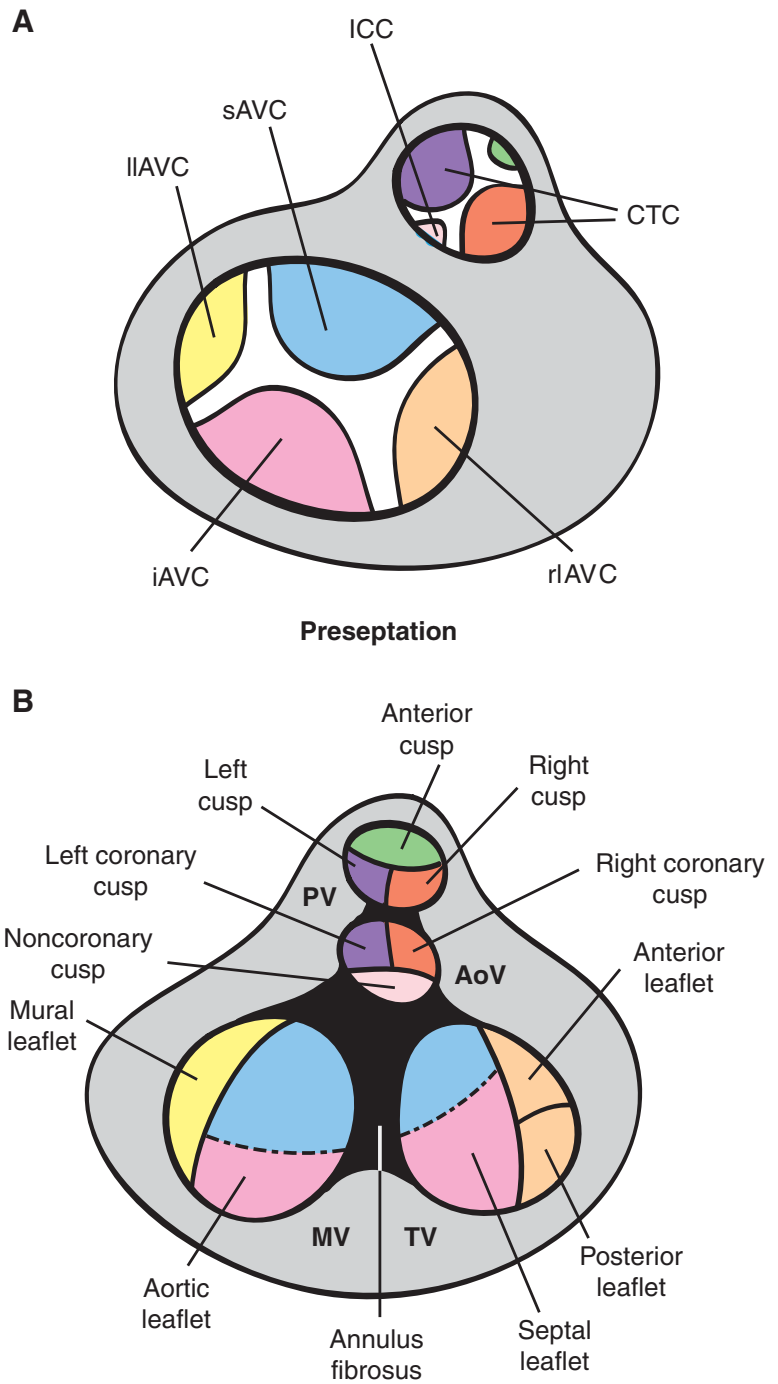

Postseptation

Figure 3. Fate of the cardiac cushions in the mature heart. Top view of the OFT preseptation $(A)$ and postseptation $(B)$. In the AVC, fusion of the major and lateral AV cushions at E13.5 results in formation of inlet valves. The sAVC (blue) contributes mostly to the aortic leaflet of the MV, whereas the iAVC (pink) contributes mostly to the septal leaflet of the TV. The rlAVC (orange) and llAVC (yellow) contribute, respectively, to the mural leaflet of the MV and anterior and posterior leaflets of the TV. These leaflets are later invaded by epicardially derived mesenchyme. The conotruncal cushions (CTCs) develop laterally right (ocre) and left (purple) in the OFT and are separated by smaller anterior (green) and posterior (light pink) intercalated cushions (ICCs). At E12.5, fusion of the CTCs yields the mesenchymal outlet septum, the right and left (R-L) cusps of the PV and R-L coronary cusps of the AoV. The ICCs give rise to the anterior leaflet of the PV and the noncoronary cusps of the AoV. Neural crest precursors invading the distal truncal ridges participate in OFT septation and contribute mesenchyme to the R-L cusps of both PV and AV. (Figure created from data adapted from Snarr et al. 2008 and Lin et al. 2012.) 
D. MacGrogan et al.
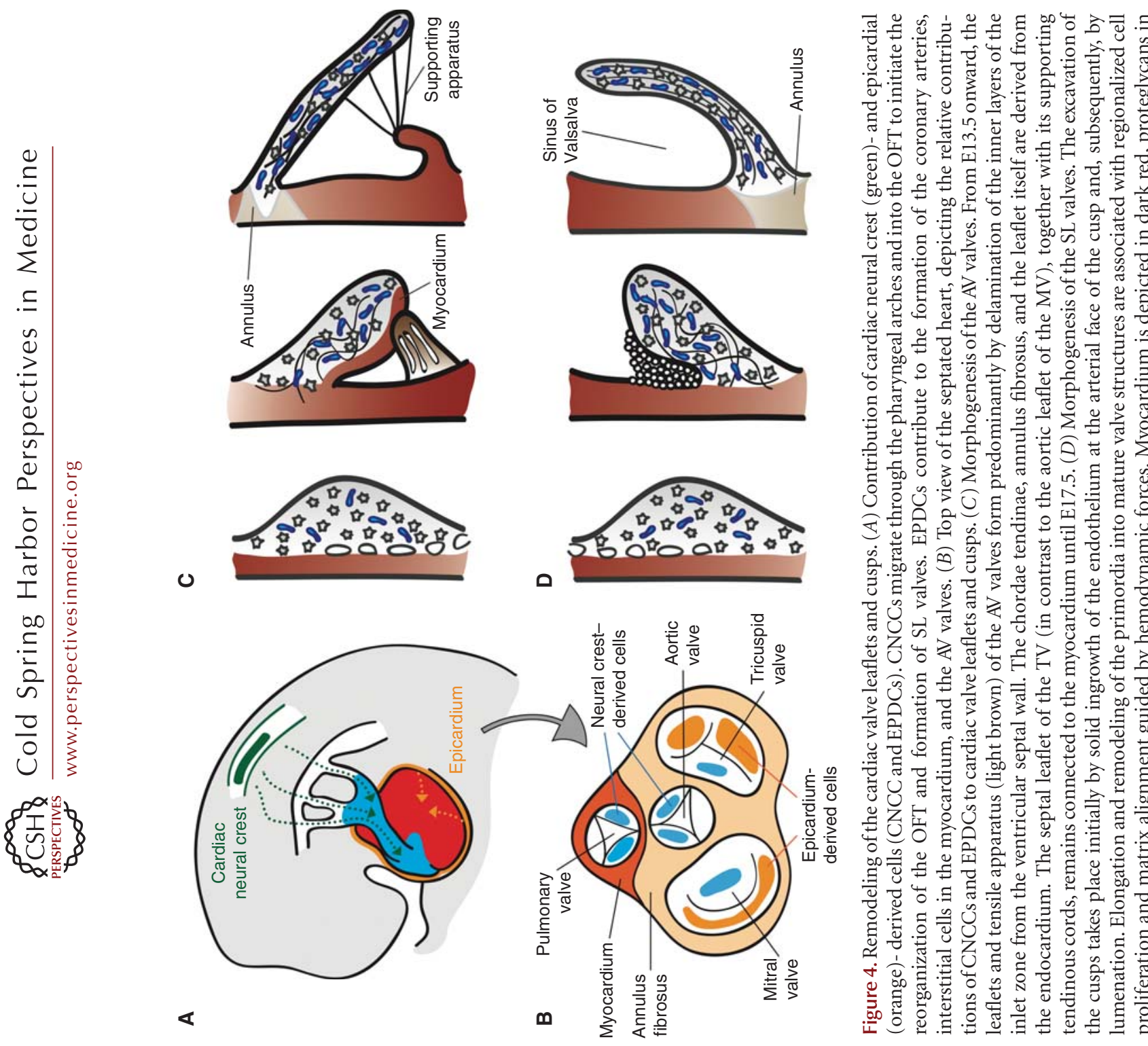

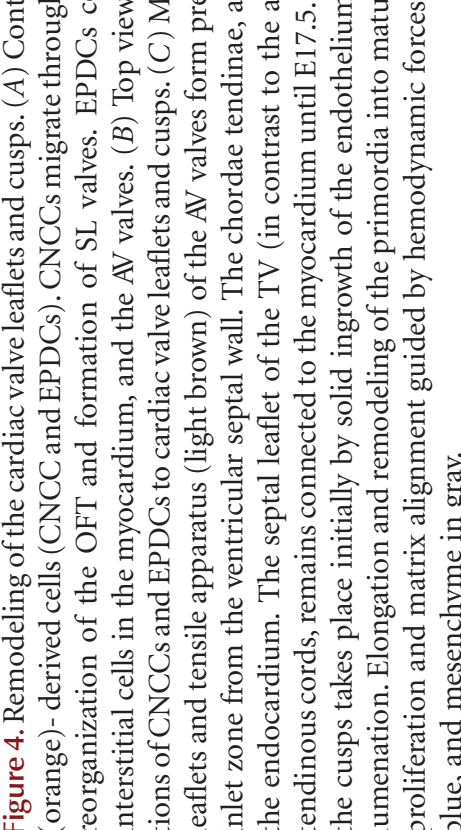


an EMT in the dorsal neural tube, CNCCs migrate into the pharyngeal arches and surround the thymus and thyroid as they form. A subset of CNCCs continues into the arterial pole of the heart to initiate the reorganization of the OFT and formation of SL valves (Hutson and Kirby 2007; Snider et al. 2008). Earlier mouse studies concluded that there was little CNCC contribution to the AV cushions (Jiang et al. 2000; de Lange et al. 2004). More recent studies with Wnt1-Cre; R26R and P0-Cre; R26R Cre reporter mice detected $\beta$-gal positive cells migrating into the $\mathrm{AV}$ canal and valves at E12.5 (Nakamura et al. 2006). These cells were found almost exclusively in the septal leaflet of the TV and aortic leaflet of MV, with the mural leaflets almost devoid of staining. Moreover, these cells persisted postnatally in the septal leaflets, as revealed by positive staining for the melanocyte marker TRP1 (Fig. 4B) (Nakamura et al. 2006).

Lineage analysis using a cGATA6-Cre; R26R Cre reporter line indicated that AVC cardiomyocytes contribute to the developing tricuspid mural and posterior leaflets and the mitral septal leaflet, and persist in the corresponding mature leaflets. The presence of $\beta$-gal-positive cells at the atrial border of the annulus fibrosus suggests that AVC cardiomyocytes contribute also to the electrical isolation of the atrial and ventricular chambers (Gaussin et al. 2005).

\section{$S L$ Valves}

At E10.5, the OFT cushions are populated by mesenchyme originating from two distinct lineages (Snarr et al. 2008; Wu et al. 2011). Tracking studies using the Tie2-Cre; ROSA26R line showed that the contribution of endocardially derived cells is restricted to the proximal portion of the conal cushions and distal part of the truncal ridges (Snarr et al. 2008; Wu et al. 2011). Cell fate analysis using Wnt1-Cre; ROSA26R reporter mice showed that CNCCs are found mostly in the distal portion wherein they form two prongs of mesenchymal cells (Fig. 4B) (Jiang et al. 2000; Nakamura et al. 2006). By E11.5, the interface of endocardium and NC-derived mesenchyme at the conotruncal junction delineates a boundary corresponding to the site of
SL valve development in humans (Anderson et al. 2003). Early fate mapping studies indicated that CNCCs present in the truncal cushions are selectively eliminated as development proceeds. As a result, it was thought that CNCCs ultimately made little substantial contribution to the valves in late-gestation embryos and postnatal animals (Jiang et al. 2000; de Lange et al. 2004). More robust fate mapping using Wnt1Cre; $R 26 R$ and P0-Cre; $R 26 R$ reporter lines, subsequently, found CNCCs persisting throughout late development and into adulthood (Nakamura et al. 2006). Remarkably, $\beta$-gal staining in this latter study concentrated in the leaflets adjacent to the aorticopulmonary septum, that is, R-L coronary cusps of the AoV and $\mathrm{R}-\mathrm{L}$ cusps of the PV (Fig. 4A). This finding is intriguing in light of the hypothesized neuralcrest origin of bicuspid aortic valve (BAV) with fusion of the R-L coronary cusps (Fernandez et al. 2009; see below).

The SHF might constitute a third source of OFT mesenchyme. Lineage tracing using Isl1Cre; $R 26 R$ mice showed that SHF cells are added to the myocardial wall as the OFT elongates before septation and contribute to endocardial lineages within the OFT (Cai et al. 2003; Yang et al. 2006). Moreover, immunohistochemical detection of Isl1 confirmed that $\mathrm{Isl1}^{+}$cells are present in the OFT myocardium and cushions (Sun et al. 2007; Snarr et al. 2008). Recent lineage tracing analysis suggests that the $\mathrm{Isl}^{+}{ }^{+}$cells are not derived solely from the SHF, but may originate also in the neural crest (Engleka et al. 2012).

Transplant repopulation experiments suggest that bone marrow (BM)-derived cells can contribute to the valve leaflets postnatally. Valves of chimeric mice transplanted with EGFP-labeled hematopoietic stem cells are $\mathrm{EGFP}^{+} / \mathrm{CD} 5^{+}$and have fibroblast-like properties characterized by collagen type I synthesis (Hajdu et al. 2011). Postnatal valve cellularization by BM-derived cells might be important for valve homeostasis, for example, by providing a population of synthetic VICs responsive to injury. Tissue bioengineering in situ takes advantage of the capacity of BM-derived cells to engraft by cell homing, and constitutes an 
D. MacGrogan et al.

attractive alternative to the classical paradigm of bioengineering ex vivo (Fig. 5).

\section{FUSION OF THE ECs}

From E11.5 onward, the ECs expand by mesenchyme proliferation driven by Bmp/TGF- $\beta$, Egf, Nf1/ras, and Wnt signaling (Gitler et al. 2003; Iwamoto et al. 2003; Jackson et al. 2003; Krenz et al. 2005; Alfieri et al. 2010) and the combined activities of highly expressed mesenchyme-specific transcription factors, including $\mathrm{Msx} 1 / 2$, Runx2, Sox9, Twist1, and Tbx20 (Gitler et al. 2003; Lincoln et al. 2007; Shelton and Yutzey 2007; Chakraborty et al. 2008, 2010). Septation of the OFT and AV junctions into separate $\mathrm{R}-\mathrm{L}$ ventricular inlets is mediated by fusion of the EC structures. In the OFT, the fusion of the larger cushions at midline yields separate outlet lumens, connecting the left and right ventricles to the AoV and PV, respectively. The primary
ECs in the AVC form a partition between atria and ventricles and determine the alignment of the $\mathrm{R}-\mathrm{L} \mathrm{AV}$ valves and proper relationship of the great arteries to the ventricular chambers (Wessels and Sedmera 2003; Snarr et al. 2008).

The mechanism(s) by which the EC fuse remain largely unknown (Hay and Low 1972). However, aberrant fusion events cause membranous ventricular septal defects and extrafusion of the AoV cusps leads to BAV. In humans, R-L fusion is the most common, followed by R-NC (Siu and Silversides 2010). A comparative study of inbred Syrian hamsters with R-L morphology and Nos3-knockout mice with R-NC morphology suggests that the etiologies of these phenotypes are different (Fernandez et al. 2009). R-L fusion may be the result of defective OFT septation, implicating the neural crest, whereas R-NC fusion may be caused by defective lateral cushion formation, suggesting inadequate EMT. The BAV is usually detected in

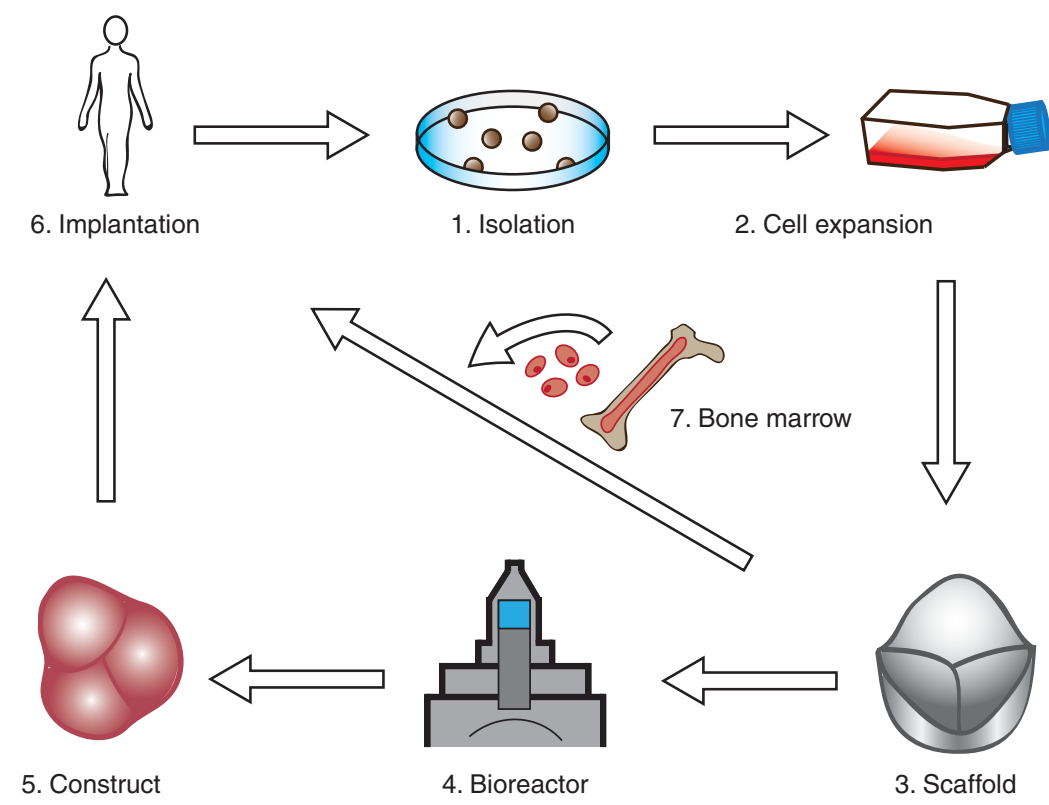

Figure 5. Valve tissue-engineering paradigm(s). (1)-(3) Conventional valve bioengineering entails a scaffold that is seeded with cells to grow a valve construct ex vivo in a bioreactor (dynamic conditioning) (4), followed by implantation in the anatomic site in vivo (5). In the modified protocol, the appropriate scaffold (3) is implanted in vivo (6) and cellularization is achieved by recruitment of circulating endothelial and mesenchymal cells from bone marrow (7). The scaffold can be engineered to incorporate molecules that stimulate recruitment, adhesion, migration, proliferation, differentiation, and cell function within the scaffold. (Figure created from data adapted from Weber et al. 2012.) 
isolation, but can also coexist with other cardiovascular malformations, suggesting a multigenic etiology (Siu and Silversides 2010). Consistent with this notion, family-based linkage analyses suggest linkage to loci on chromosome 18q, 5q, and $13 \mathrm{q}$, but the genes within these regions remain to be identified (Martin et al. 2007). To date, only mutated NOTCH1 alleles on chromosome band 9q34-35 have been found to be causative in familial BAV in the context of calcific AoV disease (Garg et al. 2005).

\section{POSTFUSION MORPHOGENESIS}

During late AV valvulogenesis, the septal leaflet of the TV remains in contact with the septum until it delaminates at E17.5 (Fig. 4C) (Lamers et al. 1995; de Lange et al. 2004; Gaussin et al. 2005). The mural leaflets of both AV valves are supported by AV myocardium at their ventricular side. In comparison, the mitral septal leaflet is never supported by myocardium, but is in contact with the AV-myocardium-derived mitral gully at its anterior and posterior margins (de Lange et al. 2004; Gaussin et al. 2005). As the primordial leaflets distend into the lumen, thin strands of elongated muscle remain attached to the valve leaflet until E17.5. Programmed cell death yields a mobile leaflet and remnants that contribute to the chordae tendinae and papillary muscles (de Lange et al. 2004; Lincoln et al. 2004). Postfusion SL valve morphogenesis is less well characterized. SL valves undergo progressive excavation from E12.5 until E15 when they achieve their typical morphology (Fig. 4D). This process is driven by "selective endothelial growth" of the free edges of the cusps on their arterial face, producing an epithelial ridge or groove between the emerging cusps and the arterial wall. The groove eventually becomes luminated to yield the sinus of Valsalva (Hurle 1979; Hurle et al. 1980).

\section{CARDIAC VALVE REMODELING}

The later phases of valve development are characterized by the gradual transition from undifferentiated mesenchyme to specialized VICs. Remodeling of the primitive ECM into a highly organized and stratified ECM is strongly influenced by hemodynamic stimuli. The developmental mechanisms that coordinate VIC specialization and ECM organization during valvulogenesis remain uncertain (de Vlaming et al. 2012).

\section{Lineage Diversification}

Cell proliferation, density, and turnover, substantial in early valvulogenesis, become less pronounced in remodeling valves (Aikawa et al. 2006; Hinton et al. 2006). Apoptosis in the OFT cushions is substantial at later fetal stages, consistent with ongoing remodeling processes (Poelmann and Gittenberger-de Groot 2005; Aikawa et al. 2006; Jain et al. 2011). Early overlapping gene expression patterns become restricted (Lincoln et al. 2004; Chakraborty et al. 2008). The transition from EC growth to remodeling requires calcineurin/NFATc1 signaling in the endocardium (de la Pompa et al. 1998; Ranger et al. 1998; Chang et al. 2004), notably through the regulation of $R A N K L$ and Cathepsin K expression (Lange and Yutzey 2006). Interstitial cell progenitors show transcriptional profiles normally associated with cartilage and tendon lineages (Lincoln et al. 2006b; Chakraborty et al. 2008). Expression of Sox9 is necessary for early interstitial cell proliferation and, subsequently, expression of cartilage matrix proteins (Akiyama et al. 2004; Lincoln et al. 2007), and scleraxis is required for tendinous cord specification (Levay et al. 2008). In the AV valves of avian embryos, Sox 9 and aggrecan are predominantly expressed in the leaflets, whereas scleraxis and tenascin $\mathrm{C}$ are expressed in the supporting AV structures, including the chordae tendineae (Lincoln et al. 2004). In contrast, SL valves express genes associated with both lineages and diversify into cusps with an internal supporting apparatus (Zhao et al. 2007). A delicate balance of BMP and fibroblast growth factors (FGF) signals is required for lineage diversification. In cultured early valve precusors, Sox 9 and aggrecan are induced by BMP2, whereas scleraxis and tenascin are regulated by FGF-4, but it is unclear how these activities coordinate spatiotemporally to 
D. MacGrogan et al.

direct VIC diversification (Lincoln et al. 2006a; Zhao et al. 2007).

\section{Remodeling of the ECM}

The elongation of the valve leaflets and stratification of the ECM begins late in gestation and continues postnatally (Aikawa et al. 2006; Hinton et al. 2006; Kruithof et al. 2007; Peacock et al. 2008; Stephens et al. 2010). Initial ECM patterning along the AV leaflet axis occurs between E15.5 and E18.5 through a transient increase in cell density called condensation (Kruithof et al. 2007). In mature valves, the ECM is found in alignment with blood flow, suggesting that stratification and remodeling are driven by hemodynamic forces acting via the endothelium (Combs and Yutzey 2009). Postnatally, additional leaflet elongation is thought to occur by physical pulling of the tendinous cord attachments by the rapidly growing ventricles.

As remodeling procedes, collagen fibrils become densely packed locally at the outflow side of the leaflet and loosely arranged and interweaving elsewhere (Aikawa et al. 2006; Hinton et al. 2006; Peacock et al. 2008; Tan et al. 2011). Fibrillogenesis is promoted by periostin, a multifunctional fascilin-domain-containing protein (Norris et al. 2009). Periostin promotes the differentiation of endothelial and epicardially derived mesenchyme while blocking other cell types, in particular, cardiomyocytes, and is required for fibrous maturation of the $\mathrm{AV}$ leaflets and their supporting apparatus (Norris et al. 2008; Snider et al. 2008). Valve remodeling and organization is dependent on the coordinated actions of MMPs and a disintegrin and metalloproteinase with thrombospondin motifs (ADAMTS) families of zinc metalloproteinases (Lockhart et al. 2011). These pericellular secreted proteases target the ECM and mediate structural changes required for cell migration and proliferation. For example, proteolytic cleavage of versican, a chondroitin sulfate proteoglycan, by ADAMTS1 plays a significant role in the maturation of the AV cushions and remodeling of the OFT by facilitating the dense packing of mesenchyme in the elongating valves (Kern et al. 2006).
Dysregulation of the ECM appears to be a general feature of valve disease regardless of etiology; for example, BAVs from pediatric patients have increased collagen and proteoglycan content, whereas myxomatous MVs have loose collagen, increased proteoglycan, and reduced elastin content with altered fiber orientation in all layers (Rabkin et al. 2001; Hinton et al. 2006; Gupta et al. 2009a). These structural changes are associated with the aberrant reexpression of early valve mesenchymal and chondrogenic progenitor markers and may be related to the reawakening of fetal transcriptional programs (Wirrig et al. 2011; Cheek et al. 2012).

\section{HEART-VALVE TISSUE ENGINEERING}

\section{General Overview}

In the classical tissue-engineering paradigm, cells are harvested from a donor (which can be the recipient) and are subsequently expanded to obtain a sufficiently large number of cells for seeding on a biodegradable starter matrix (scaffold) (Fig. 5). The porous starter matrix is shaped like a heart valve and supports the formation of neotissue (Hoerstrup et al. 2000). In the bioreactor, the construct is subjected to biochemical and mechanical stimuli to enhance the production of ECM proteins in an effort to create a valve that has sufficient strength and durability to meet in vivo hemodynamic requirements (Mol et al. 2005a; Kortsmit et al. 2009). Particular attention has been focused on replicating the anisotropic architecture of the native leaflet (Mol et al. 2006; Neidert and Tranquillo 2006; Balguid et al. 2007; Rubbens et al. 2009; Cox et al. 2010; Sander et al. 2011).

An alternative approach is autologous tissue formation, initiated by intraperitoneal implantation of a heart valve-shaped scaffold (De Visscher et al. 2007) or mold (Hayashida et al. 2007; Yamanami et al. 2010). The mold will elicit a foreign body response causing deposition of autologous ECM on the mold surface. The resulting construct is then transplanted to the heart as a valve replacement. However, the volume fraction of cellular phenotypes currently achieved with this approach is unbalanced, 
which may result in inadequate remodeling of the valves (De Visscher et al. 2007).

\section{Cell Sources for In Vitro Heart-Valve Tissue Engineering}

A large variety of cell types has been investigated for in vitro seeding of synthetic or biological scaffolds. Early experiments comparing the in vivo response to allogenic and autologous cells showed that seeded cells from an autologous source were desirable to minimize the immune response (Shinoka et al. 1995). However, autologous cells were recently shown to provoke an immune response caused by proinflammatory cytokines originating from cell death, or damage-associated molecular pattern (DAMP) molecules released by dying cells within the autologous tissue (Badylak and Gilbert 2008).

Vascular-derived myofibroblasts and endothelial cells are the gold standard in heart-valve tissue engineering because of their excellent ECM production capacity. These cells can be harvested from the recipient's saphenous vein. Alternative sources are progenitor cells derived from bone marrow, adipose tissue or umbilical cord blood, and circulating endothelial progenitor cells, all of which have shown potential to provide interstitial and endothelial function and have been used to generate heart valves in vitro (Hoerstrup et al. 2002; Schmidt et al. 2007; Sales et al. 2010). One of the advantages of progenitor cells is that, unlike vascular-derived cells, they can be harvested without additional surgical intervention. In this regard, bone marrow-derived mesenchymal stem cells (MSCs) are attractive candidates and have been used to seed decellularized matrices (Vincentelli et al. 2007; Iop et al. 2009) and synthetic scaffolds (Hoerstrup et al. 2002; Sutherland et al. 2005). MSCs are remarkably similar to VICs (Latif et al. 2007), and have antithrombogenic (Hashi et al. 2007) and immunosuppressive properties (Uccelli et al. 2006). MSCs are able to differentiate into endothelial cells, fibroblasts or myofibroblasts, and smooth muscle cells (Iop et al. 2009). Their accessibility, ease of handling, and potential for allogenic applications make MSCs suitable for routine clinical use (Pittenger and Martin 2004).
In addition to supporting proliferation, differentiation, and ECM production ex vivo, MSCs can induce the homing and differentiation of autologous host cells through paracrine signaling, involving an array of cytokines and growth factors (Roh et al. 2010). Despite the encouraging results obtained with preseeded scaffolds in sheep and baboons (Vincentelli et al. 2007; Weber et al.2011), the antithrombogenic properties of MSCs (Hashi et al. 2007) and their ability to stimulate in vivo endothelialization (Mirza et al. 2008) should preclude future requirements for preseeding with endothelial cells.

\section{Scaffolds for Heart-Valve Tissue Engineering}

Different types of scaffold materials, or so-called starter matrices, have been used for heart-valve tissue engineering. These include biodegradable synthetic polymers, natural materials, such as fibrin and collagen, and xenogenic or allogenic decellularized heart valves. A decellularized xenograft or homograft is an obvious choice of scaffold material because these grafts closely resemble native human valve geometry and structure and have excellent mechanical and hemodynamic properties. The microstructure of the allograft favors proliferation, differentiation, and survival of reseeded cells (Mirza et al. 2008). The use of allografts, however, is limited by donor availability. Because of its anatomic similarity to human valves, the porcine heart valve makes an attractive alternative. Clinical application of decellularized xenografts has, however, resulted in early failure (Simon et al. 2003; Roh et al. 2010; Ruffer et al. 2010; Hibino et al. 2011). A major concern with xenogenic materials is infection with endogenous porcine retroviruses, prions, or other zoonotic vectors. Improved decellularization techniques recently allowed the preparation of nonimmunogenic decellularized xenograft valves (Bloch et al. 2011). Complete removal of cells from the tissue is crucial, as residual cells and cell remnants within the matrix might lead to calcification (Human and Zilla 2001). It is also important to minimize structural alteration of the ECM to preserve the biomechanical characteristics of the native heart valve. A promising alternative 
D. MacGrogan et al.

is the use of decellularized TEHVs, yielding offthe-shelf available homologous heart valves (Dijkman et al. 2012).

Biodegradable synthetic materials have been widely used as scaffold material for tissue engineering (Bouten et al. 2011). Commonly used biomaterials are different copolymers and derivatives thereof, whereas, more recently, elastomeric materials have gained attention (Courtney et al. 2006; Sales et al. 2007; Stella et al. 2010). Compared with decellularized xenogenic and allogenic matrices, these materials avoid the risk of disease transfer and immunological complications. In addition, synthetic materials have the advantage of unlimited supply and their biological, mechanical, and degradation properties can be tailored to the specific application. Synthetic scaffold materials have also been combined with natural substrates, such as ECM components (e.g., collagen) and fibrin. Fibrin, in particular, has been frequently used as scaffold material (Ye et al. 2000; Syedain et al. 2008; Flanagan et al. 2009), either alone or in combination with a synthetic scaffold (Mol et al. 2005b). After seeding the scaffold with the selected cell source, the construct is subsequently exposed to biochemical and mechanical cues in a bioreactor to stimulate ECM formation. When seeded with autologous cells and then cultured in vitro, these materials have been shown to be suitable for heart-valve tissue engineering, with functionality shown in vitro and in vivo (Hoerstrup et al. 2000; Sutherland et al. 2005; Flanagan et al. 2009; Gottlieb et al. 2010; Schmidt et al. 2010).

\section{In Situ Tissue Engineering Using Synthetic Scaffolds}

An emerging alternative is tissue engineering in situ using synthetic biodegradable scaffolds and endogenous cells (Roh et al. 2010), either recruited from the bloodstream or harvested on the fly (Weber et al. 2011). This approach is supported by recent findings that dramatically alter the view of the role of the seeded cells in relation to in vivo cell recruitment. These findings show that bone marrow-derived mononuclear cells (BM-MNCs) seeded onto a biodegradable scaf- fold are rapidly replaced by host cells when implanted either as a vascular graft in severe combined immunodeficiency (SCID)/beige (bg) mice (Roh et al. 2010) or a heart valve in a nonhuman primate model (Weber et al. 2011). The evidence suggests that the seeded BMMNCs play a paracrine-signaling role during in vivo tissue formation. This further suggests that, even without preseeding, mature tissue might be obtained via an inflammation-mediated process in which infiltration of circulating monocytes into the scaffold is stimulated and controlled by the release of specific cytokines (e.g., monocyte chemotactic protein [MCP]1). All implanted biomaterials trigger an inflammatory host response, which is essential for the colonization of starter matrices by blood-derived cells. The nature and differentiation of the infiltrating cells are of pivotal importance to the delicate balance that determines generation of a fibrotic or functional ECM (Roh et al. 2010; Hibino et al. 2011). The inflammatory process and subsequent fibrosis or regeneration are tightly controlled, both spatially and temporally, by a plethora of cytokines that regulate secondary cellular homing, infiltrated cell differentiation, and ensuing ECM production. An important cytokine guiding the inflammatory process toward regeneration is MCP- 1 , a chemokine secreted by macrophages to attract additional inflammatory cells, resulting in rapid and homogenous infiltration of the starter matrix with blood-derived cells. MCP-1 has, moreover, proved to be an important chemokine in the regulation of macrophage polarization toward a reparative phenotype (Roh et al. 2010). Stromal cell-derived factor (SDF)- $1 \alpha$ is critical for attracting blood-derived tissue-producing progenitor cells and controlling valvular cell phenotype (De Visscher et al. 2010). TGF- $\beta$, during the initial inflammatory phase, contributes to polarization of macrophages toward the reparative phenotype, but because of its profibrotic actions, it should be suppressed during later inflammatory phases (De Visscher et al. 2010).

The mechanical and biological requirements to the scaffold materials used for tissue engineering in situ are quite different from those used for the tissue engineering in vitro 
(Bouten et al. 2011, 2012). In addition to meeting generic biocompatibility requirements, the implanted scaffold must be durable and able to carry the hemodynamic load so that its degradation properties align with the time scale of in vivo synthesis of ECM proteins.

\section{Challenges in Heart-Valve Tissue Engineering}

Preclinical experiments in sheep using in vitro engineered heart valves have highlighted two main problems, thickening and retraction of the leaflets, leading to unacceptable valve regurgitation (Schmidt et al. 2007; Flanagan et al. 2009; Gottlieb et al. 2010; Syedain et al. 2013). Furthermore, both the radial and circumferential length of the leaflets decreased over time. The retraction phenomenon appears to be independent of the scaffold material and cell source because it was observed in fibrin-based scaffold using fibroblasts (Syedain et al. 2013) or myofibroblasts (Flanagan et al. 2009), polyglycolic acid (PGA) coated with a poly-4-hydroxybutyrate (P4HB) scaffold and myofibroblasts (Schmidt et al. 2010), and a PGA-PLLA [PGApoly(L-lactic acid]) scaffold with BM-MNCs (Gottlieb et al. 2010). Cell-mediated retraction of the leaflets might be compensated for by creating longer leaflets (Neidert and Tranquillo 2006) or adding a slowly degrading additional support scaffold next to the fibrin scaffold (Flanagan et al. 2009). Attempts have been made to reduce cell-mediated retraction by adding the myosin inhibitor blebbistatin (Syedain et al. 2013), but although this reduced cell-mediated retraction initially, leaflet retraction remained apparent beyond 4 weeks. The passive and active contribution of cells to the generated traction forces in tissue-engineered strips have been identified independently (van Vlimmeren et al. 2012). Active cell traction forces were eliminated by treatment with cytochalasin $\mathrm{D}$ to disrupt the actin cytoskeleton, and inhibition of the Rho-associated kinase pathway. The passive contribution of the cell can be examined by decellularizing the tissue construct. Cell-mediated retraction accounted for $85 \%$ of the observed retraction, with the remaining $15 \%$ attributed to residual stresses in the matrix; this validates the use of decellularization to substantially reduce cell-mediated retraction in TEHVs (Dijkman et al. 2012). Subsequently, reseeding of decelluarized valves with bone marrowderived MSCs does not appear to reintroduce cell-mediated retraction in vitro (Dijkman et al. 2012; Syedain et al. 2013).

Decellularized xenografts and homografts are in clinical use. In animal models, decellularized valves recellularize slowly and only partially in vivo (Goldstein et al. 2000; Elkins et al. 2001; Leyh et al. 2003; Erdbrugger et al. 2006). In humans, in vivo recellularizaton of xenografts remains uncertain (Sayk et al. 2005), and clinical failures have been reported (Simon et al. 2003; Ruffer et al. 2010; Lepage et al. 2012), including complete destruction of a porcine xenograft (Hiemann et al. 2010). Decellularized homografts (Cebotari et al. 2006), because they are less thrombogenic and carry a lower risk of infection, may be more appropriate for human application (Rieder et al. 2005). Recellularization has been observed in a cryopreserved aortic homograft 2 years after implantation (Miller et al. 2006). Freshly decellularized homografts for PV replacements showed improved intermediate performance compared with traditional bioprosthetic valves and cryopreserved homografts in children (Cebotari et al. 2011). However, limited donor availability may inhibit the widespread use of the decellularized homografts, in particular, for young patients.

\section{CONCLUSIONS AND PERSPECTIVES}

Significant advances in valve development genetics over the past decade have helped to decipher the underlying causes of valve disease in newborns and adults. The unifying concept that has emerged is that most, if not all, valve disease has its origin during embryogenesis, either as the manifestation of developmental processes gone awry or the aberrant reexpression of fetal gene programs normally quiescent in adulthood. The manipulation of these processes in transgenic lines and the availability of the 3D collagen explant approach have led to the identification of many signaling pathways critical for EMT. However, much remains to be under- 
D. MacGrogan et al.

stood about post-EMT valve morphogenesis. Attributable to their iterative use, most signaling pathways critical for EMT are also critical for post-EMT developmental processes and result in early embryonic lethality when genetically removed. Lack of adequate in vivo models of post-EMT events is related to the absence of valve-specific mesenchyme enhancer(s); the creation of conditional or inducible models specifically affecting valve mesenchyme will go some way to providing answers.

Progress in heart valve bioengineering requires further understanding of the molecular cascades active during cardiac valve formation to enable more efficient ex vivo differentiation of valve progenitor cells. Recent advances in stem-cell biology, such as the discovery of induced pluripotent cells and improved protocols for differentiating endocardial and endothelial lineages, may provide solutions for the design of constructs that more closely match the patients' genetic makeup. Another important advance will be the design of biomaterials, which permits control of cell behavior in engineered valves in situ, thereby promoting more efficient recruitment of endogenous cells.

\section{ACKNOWLEDGMENTS}

We thank S. Bartlett (Centro Nacional de Investigaciones Cardiovasculares [CNIC]) for English editing. We apologize to colleagues for omissions because of space limitations. J.L.d.l.P. is funded by Grants SAF2010-17555, RD12/ 0042/0005 (RIC), and RD12/0019/0003 (TERCEL) from the Spanish Ministry of Economy and Competition (MINECO). The CNIC is supported by the Ministerio de Ciencia e Innovacion (MICINN) and the Pro-CNIC Foundation.

\section{REFERENCES}

Abu-Issa R, Kirby ML. 2007. Heart field: From mesoderm to heart tube. Annu Rev Cell Dev Biol 23: 45-68.

Aikawa E, Whittaker P, Farber M, Mendelson K, Padera RF, Aikawa M, Schoen FJ. 2006. Human semilunar cardiac valve remodeling by activated cells from fetus to adult: Implications for postnatal adaptation, pathology, and tissue engineering. Circulation 113: 1344-1352.
Akiyama H, Chaboissier MC, Behringer RR, Rowitch DH, Schedl A, Epstein JA, de Crombrugghe B. 2004. Essential role of Sox9 in the pathway that controls formation of cardiac valves and septa. Proc Natl Acad Sci 101: 65026507.

Alfieri CM, Cheek J, Chakraborty S, Yutzey KE. 2010. Wnt signaling in heart valve development and osteogenic gene induction. Dev Biol 338: 127-135.

Anderson RH, Webb S, Brown NA, Lamers W, Moorman A. 2003. Development of the heart: (3) Formation of the ventricular outflow tracts, arterial valves, and intrapericardial arterial trunks. Heart 89: 1110-1118.

Armstrong EJ, Bischoff J. 2004. Heart valve development: Endothelial cell signaling and differentiation. Circ Res 95: 459-470.

Badylak SF, Gilbert TW. 2008. Immune response to biologic scaffold materials. Semin Immunol 20: 109-116.

Balachandran K, Sucosky P, Jo H, Yoganathan AP. 2009. Elevated cyclic stretch alters matrix remodeling in aortic valve cusps: Implications for degenerative aortic valve disease. Am J Physiol Heart Circ Physiol 296: H756-H764.

Balguid A, Rubbens MP, Mol A, Bank RA, Bogers AJ, van Kats JP, de Mol BA, Baaijens FP, Bouten CV. 2007. The role of collagen cross-links in biomechanical behavior of human aortic heart valve leaflets-Relevance for tissue engineering. Tissue Eng 13: 1501-1511.

Bischoff J, Aikawa E. 2011. Progenitor cells confer plasticity to cardiac valve endothelium. J Cardiovasc Transl Res 4: 710-719.

Bloch O, Golde P, Dohmen PM, Posner S, Konertz W, Erdbrugger W. 2011. Immune response in patients receiving a bioprosthetic heart valve: Lack of response with decellularized valves. Tissue Eng Part A 17: 2399-2405.

Bouten CV, Dankers PY, Driessen-Mol A, Pedron S, Brizard AM, Baaijens FP. 2011. Substrates for cardiovascular tissue engineering. Adv Drug Deliv Rev 63: 221-241.

Bouten CV, Driessen-Mol A, Baaijens FP. 2012. In situ heart valve tissue engineering: Simple devices, smart materials, complex knowledge. Exp Rev Med Devices 9: 453-455.

Brand T. 2003. Heart development: Molecular insights into cardiac specification and early morphogenesis. Dev Biol 258: $1-19$.

Buckingham M, Meilhac S, Zaffran S. 2005. Building the mammalian heart from two sources of myocardial cells. Nat Rev Genet 6: 826-835.

Butcher JT, Markwald RR. 2007. Valvulogenesis: The moving target. Philos Trans R Soc Lond B Biol Sci 362: 14891503.

Butcher JT, Nerem RM. 2004. Porcine aortic valve interstitial cells in three-dimensional culture: Comparison of phenotype with aortic smooth muscle cells. J Heart Valve Dis 13: 485-476.

Butcher JT, Nerem RM. 2006. Valvular endothelial cells regulate the phenotype of interstitial cells in co-culture: Effects of steady shear stress. Tissue Eng 12: 905-915.

Cai CL, Liang X, Shi Y, Chu PH, Pfaff SL, Chen J, Evans S. 2003. Isl1 identifies a cardiac progenitor population that proliferates prior to differentiation and contributes a majority of cells to the heart. Dev Cell 5: 877-889.

Camenisch TD, Schroeder JA, Bradley J, Klewer SE, McDonald JA. 2002. Heart-valve mesenchyme formation 
is dependent on hyaluronan-augmented activation of ErbB2-ErbB3 receptors. Nat Med 8: 850-855.

Cebotari S, Lichtenberg A, Tudorache I, Hilfiker A, Mertsching H, Leyh R, Breymann T, Kallenbach K, Maniuc L, Batrinac A, et al. 2006. Clinical application of tissue engineered human heart valves using autologous progenitor cells. Circulation 114: I132-I137.

Cebotari S, Tudorache I, Ciubotaru A, Boethig D, Sarikouch S, Goerler A, Lichtenberg A, Cheptanaru E, Barnaciuc S, Cazacu A, et al. 2011. Use of fresh decellularized allografts for pulmonary valve replacement may reduce the reoperation rate in children and young adults: Early report. Circulation 124: S115-S123.

Chakraborty S, Cheek J, Sakthivel B, Aronow BJ, Yutzey KE. 2008. Shared gene expression profiles in developing heart valves and osteoblast progenitor cells. Physiol Genomics 35: 75-85.

Chakraborty S, Wirrig EE, Hinton RB, Merrill WH, Spicer DB, Yutzey KE. 2010. Twist1 promotes heart valve cell proliferation and extracellular matrix gene expression during development in vivo and is expressed in human diseased aortic valves. Dev Biol 347: 167-179.

Chang CP, Neilson JR, Bayle JH, Gestwicki JE, Kuo A, Stankunas K, Graef IA, Crabtree GR. 2004. A field of myocardial-endocardial NFAT signaling underlies heart valve morphogenesis. Cell 118: 649-663.

Cheek JD, Wirrig EE, Alfieri CM, James JF, Yutzey KE. 2012. Differential activation of valvulogenic, chondrogenic, and osteogenic pathways in mouse models of myxomatous and calcific aortic valve disease. J Mol Cell Cardiol 52: 689-700.

Chen JH, Simmons CA. 2011. Cell-matrix interactions in the pathobiology of calcific aortic valve disease: Critical roles for matricellular, matricrine, and matrix mechanics cues. Circ Res 108: 1510-1524.

Combs MD, Yutzey KE. 2009. Heart valve development: Regulatory networks in development and disease. Circ Res 105: 408-421.

Courtney T, Sacks MS, Stankus J, Guan J, Wagner WR. 2006. Design and analysis of tissue engineering scaffolds that mimic soft tissue mechanical anisotropy. Biomaterials 27: 3631-3638.

Cox MA, Kortsmit J, Driessen N, Bouten CV, Baaijens FP. 2010. Tissue-engineered heart valves develop native-like collagen fiber architecture. Tissue Eng Part A 16: 15271537.

de Lange FJ, Moorman AF, Anderson RH, Manner J, Soufan AT, de Gier-de Vries C, Schneider MD, Webb S, van den Hoff MJ, Christoffels VM. 2004. Lineage and morphogenetic analysis of the cardiac valves. Circ Res 95: 645-654.

de la Pompa JL, Epstein JA. 2012. Coordinating tissue interactions: Notch signaling in cardiac development and disease. Dev Cell 22: 244-254.

de la Pompa JL, Timmerman LA, Takimoto H, Yoshida H, Elia AJ, Samper E, Potter J, Wakeham A, Marengere L, Langille BL, et al. 1998. Role of the NF-ATc transcription factor in morphogenesis of cardiac valves and septum. Nature 392: 182-186.

Del Monte G, Grego-Bessa J, Gonzalez-Rajal A, Bolos V, De La Pompa JL. 2007. Monitoring Notch1 activity in development: Evidence for a feedback regulatory loop. Dev Dyn 236: 2594-2614.
De Visscher G, Vranken I, Lebacq A, Van Kerrebroeck C, Ganame J, Verbeken E, Flameng W. 2007. In vivo cellularization of a cross-linked matrix by intraperitoneal implantation: A new tool in heart valve tissue engineering. Eur Heart J 28: 1389-1396.

De Visscher G, Lebacq A, Mesure L, Blockx H, Vranken I, Plusquin R, Meuris B, Herregods MC, Van Oosterwyck H, Flameng W. 2010. The remodeling of cardiovascular bioprostheses under influence of stem cell homing signal pathways. Biomaterials 31: 20-28.

de Vlaming A, Sauls K, Hajdu Z, Visconti RP, Mehesz AN, Levine RA, Slaugenhaupt SA, Hagege A, Chester AH, Markwald RR, et al. 2012. Atrioventricular valve development: New perspectives on an old theme. Differentiation 84: 103-116.

Dijkman PE, Driessen-Mol A, Frese L, Hoerstrup SP, Baaijens FP. 2012. Decellularized homologous tissue-engineered heart valves as off-the-shelf alternatives to xenoand homografts. Biomaterials 33: 4545-4554.

Dor Y, Camenisch TD, Itin A, Fishman GI, McDonald JA, Carmeliet P, Keshet E. 2001. A novel role for VEGF in endocardial cushion formation and its potential contribution to congenital heart defects. Development 128: 1531-1538.

Dyer LA, Kirby ML. 2009. The role of secondary heart field in cardiac development. Dev Biol 336: 137-144.

Egorova AD, Khedoe PP, Goumans MJ, Yoder BK, Nauli SM, ten Dijke P, Poelmann RE, Hierck BP. 2011. Lack of primary cilia primes shear-induced endothelial-to-mesenchymal transition. Circ Res 108: 1093-1101.

Eisenberg LM, Markwald RR. 1995. Molecular regulation of atrioventricular valvuloseptal morphogenesis. Circ Res 77: 1-6.

El-Hamamsy I, Balachandran K, Yacoub MH, Stevens LM, Sarathchandra P, Taylor PM, Yoganathan AP, Chester AH. 2009. Endothelium-dependent regulation of the mechanical properties of aortic valve cusps. J Am Coll Cardiol 53: 1448-1455.

El-Hamamsy I, Eryigit Z, Stevens LM, Sarang Z, George R, Clark L, Melina G, Takkenberg JJ, Yacoub MH. 2010. Long-term outcomes after autograft versus homograft aortic root replacement in adults with aortic valve disease: A randomised controlled trial. Lancet 376: 524-531.

Elkins RC, Goldstein S, Hewitt CW, Walsh SP, Dawson PE, Ollerenshaw JD, Black KS, Clarke DR, O’Brien MF. 2001. Recellularization of heart valve grafts by a process of adaptive remodeling. Semin Thorac Cardiovasc Surg 13: 87-92.

Engleka KA, Manderfield LJ, Brust RD, Li L, Cohen A, Dymecki SM, Epstein JA. 2012. Islet1 derivatives in the heart are of both neural crest and second heart field origin. Circ Res 110: 922-926.

Erdbrugger W, Konertz W, Dohmen PM, Posner S, Ellerbrok H, Brodde OE, Robenek H, Modersohn D, Pruss A, Holinski S, et al. 2006. Decellularized xenogenic heart valves reveal remodeling and growth potential in vivo. Tissue Eng 12: 2059-2068.

Fernandez B, Duran AC, Fernandez-Gallego T, Fernandez MC, Such M, Arque JM, Sans-Coma V. 2009. Bicuspid aortic valves with different spatial orientations of the leaflets are distinct etiological entities. J Am Coll Cardiol 54: $2312-2318$.

Flanagan TC, Sachweh JS, Frese J, Schnoring H, Gronloh N, Koch S, Tolba RH, Schmitz-Rode T, Jockenhoevel S. 2009. 
D. MacGrogan et al.

In vivo remodeling and structural characterization of fibrin-based tissue-engineered heart valves in the adult sheep model. Tissue Eng Part A 15: 2965-2976.

Fondard O, Detaint D, Iung B, Choqueux C, Adle-Biassette H, Jarraya M, Hvass U, Couetil JP, Henin D, Michel JB, et al. 2005. Extracellular matrix remodelling in human aortic valve disease: The role of matrix metalloproteinases and their tissue inhibitors. Eur Heart J 26: 1333-1341.

Garg V, Muth AN, Ransom JF, Schluterman MK, Barnes R, King IN, Grossfeld PD, Srivastava D. 2005. Mutations in NOTCH1 cause aortic valve disease. Nature 437: 270 274.

Gaussin V, Morley GE, Cox L, Zwijsen A, Vance KM, Emile L, Tian Y, Liu J, Hong C, Myers D, et al. 2005. Alk3/ Bmprla receptor is required for development of the atrioventricular canal into valves and annulus fibrosus. Circ Res 97: 219-226.

Gessert S, Kuhl M. 2010. The multiple phases and faces of wnt signaling during cardiac differentiation and development. Circ Res 107: 186-199.

Gitler AD, Zhu Y, Ismat FA, Lu MM, Yamauchi Y, Parada LF, Epstein JA. 2003. Nf1 has an essential role in endothelial cells. Nat Genet 33: 75-79.

Gittenberger-de Groot AC, Vrancken Peeters MP, Mentink MM, Gourdie RG, Poelmann RE. 1998. Epicardium-derived cells contribute a novel population to the myocardial wall and the atrioventricular cushions. Circ Res 82: 1043-1052.

Goldstein S, Clarke DR, Walsh SP, Black KS, O’Brien MF. 2000. Transpecies heart valve transplant: Advanced studies of a bioengineered xeno-autograft. Ann Thorac Surg 70: 1962-1969.

Gottlieb D, Kunal T, Emani S, Aikawa E, Brown DW, Powell AJ, Nedder A, Engelmayr GC Jr, Melero-Martin JM, Sacks MS, et al. 2010. In vivo monitoring of function of autologous engineered pulmonary valve. J Thorac Cardiovasc Surg 139: 723-731.

Gupta V, Grande-Allen KJ. 2006. Effects of static and cyclic loading in regulating extracellular matrix synthesis by cardiovascular cells. Cardiovasc Res 72: 375-383.

Gupta V, Barzilla JE, Mendez JS, Stephens EH, Lee EL, Collard CD, Laucirica R, Weigel PH, Grande-Allen KJ. 2009a. Abundance and location of proteoglycans and hyaluronan within normal and myxomatous mitral valves. Cardiovasc Pathol 18: 191-197.

Gupta V, Tseng H, Lawrence BD, Grande-Allen KJ. 2009b. Effect of cyclic mechanical strain on glycosaminoglycan and proteoglycan synthesis by heart valve cells. Acta Biomater 5: 531-540.

Guy TS, Hill AC. 2012. Mitral valve prolapse. Annu Rev Med 63: $277-292$.

Hajdu Z, Romeo SJ, Fleming PA, Markwald RR, Visconti RP, Drake CJ. 2011. Recruitment of bone marrow-derived valve interstitial cells is a normal homeostatic process. $J$ Mol Cell Cardiol 51: 955-965.

Harvey RP. 2002. Patterning the vertebrate heart. Nat Rev Genet 3: 544-556.

Hashi CK, Zhu Y, Yang GY, Young WL, Hsiao BS, Wang K, Chu B, Li S. 2007. Antithrombogenic property of bone marrow mesenchymal stem cells in nanofibrous vascular grafts. Proc Natl Acad Sci 104: 11915-11920.
Hay DA, Low FN. 1972. The fusion of dorsal and ventral endocardial cushions in the embryonic chick heart: A study in fine structure. Am J Anat 133: 1-23.

Hayashida K, Kanda K, Yaku H, Ando J, Nakayama Y. 2007. Development of an in vivo tissue-engineered, autologous heart valve (the biovalve): Preparation of a prototype model. J Thorac Cardiovasc Surg 134: 152-159.

Hibino N, Yi T, Duncan DR, Rathore A, Dean E, Naito Y, Dardik A, Kyriakides T, Madri J, Pober JS, et al. 2011. A critical role for macrophages in neovessel formation and the development of stenosis in tissue-engineered vascular grafts. FASEB J 25: 4253-4263.

Hiemann NE, Mani M, Huebler M, Meyer R, Hetzer R, Thieme R, Bethge C. 2010. Complete destruction of a tissue-engineered porcine xenograft in pulmonary valve position after the Ross procedure. $J$ Thorac Cardiovasc Surg 139: e67-e68.

Hinton RB, Yutzey KE. 2011. Heart valve structure and function in development and disease. Annu Rev Physiol 73: $29-46$

Hinton RB Jr, Lincoln J, Deutsch GH, Osinska H, Manning PB, Benson DW, Yutzey KE. 2006. Extracellular matrix remodeling and organization in developing and diseased aortic valves. Circ Res 98: 1431-1438.

Hoerstrup SP, Sodian R, Daebritz S, Wang J, Bacha EA, Martin DP, Moran AM, Guleserian KJ, Sperling JS, Kaushal S, et al. 2000. Functional living trileaflet heart valves grown in vitro. Circulation 102: III44-III49.

Hoerstrup SP, Kadner A, Melnitchouk S, Trojan A, Eid K, Tracy J, Sodian R, Visjager JF, Kolb SA, Grunenfelder J, et al. 2002. Tissue engineering of functional trileaflet heart valves from human marrow stromal cells. Circulation 106: I143-I150.

Human P, Zilla P. 2001. The possible role of immune responses in bioprosthetic heart valve failure. J Heart Valve Dis 10: $460-466$.

Hurle JM. 1979. Scanning and light microscope studies of the development of the chick embryo semilunar heart valves. Anat Embryol (Berl) 157: 69-80.

Hurle JM, Colvee E, Blanco AM. 1980. Development of mouse semilunar valves. Anat Embryol (Berl) 160: 83-91.

Hutson MR, Kirby ML. 2007. Model systems for the study of heart development and disease. Cardiac neural crest and conotruncal malformations. Semin Cell Dev Biol 18: $101-110$.

Iop L, Renier V, Naso F, Piccoli M, Bonetti A, Gandaglia A, Pozzobon M, Paolin A, Ortolani F, Marchini M, et al. 2009. The influence of heart valve leaflet matrix characteristics on the interaction between human mesenchymal stem cells and decellularized scaffolds. Biomaterials 30: 4104-4116.

Iwamoto R, Mekada E. 2006. ErbB and HB-EGF signaling in heart development and function. Cell Struct Funct 31: $1-14$.

Iwamoto R, Yamazaki S, Asakura M, Takashima S, Hasuwa H, Miyado K, Adachi S, Kitakaze M, Hashimoto K, Raab G, et al. 2003. Heparin-binding EGF-like growth factor and ErbB signaling is essential for heart function. Proc Natl Acad Sci 100: 3221-3226.

Jackson LF, Qiu TH, Sunnarborg SW, Chang A, Zhang C, Patterson C, Lee DC. 2003. Defective valvulogenesis in 
HB-EGF and TACE-null mice is associated with aberrant BMP signaling. EMBO J 22: 2704-2716.

Jain R, Engleka KA, Rentschler SL, Manderfield LJ, Li L, Yuan L, Epstein JA. 2011. Cardiac neural crest orchestrates remodeling and functional maturation of mouse semilunar valves. J Clin Invest 121: 422-430.

Jiang X, Rowitch DH, Soriano P, McMahon AP, Sucov HM. 2000. Fate of the mammalian cardiac neural crest. Development 127: 1607-1616.

Joziasse IC, van de Smagt JJ, Smith K, Bakkers J, Sieswerda GJ, Mulder BJ, Doevendans PA. 2008. Genes in congenital heart disease: Atrioventricular valve formation. Basic Res Cardiol 103: 216-227.

Kelly RG, Buckingham ME. 2002. The anterior heart-forming field: Voyage to the arterial pole of the heart. Trends Genet 18: 210-216.

Kern CB, Twal WO, Mjaatvedt CH, Fairey SE, Toole BP, Iruela-Arispe ML, Argraves WS. 2006. Proteolytic cleavage of versican during cardiac cushion morphogenesis. Dev Dyn 235: 2238-2247.

Kokubo H, Tomita-Miyagawa S, Hamada Y, Saga Y. 2007. Hesr 1 and Hesr2 regulate atrioventricular boundary formation in the developing heart through the repression of Tbx2. Development 134: 747-755.

Kortsmit J, Driessen NJ, Rutten MC, Baaijens FP. 2009. Real time, non-invasive assessment of leaflet deformation in heart valve tissue engineering. Ann Biomed Eng 37: $532-541$.

Krenz M, Yutzey KE, Robbins J. 2005. Noonan syndrome mutation Q79R in Shp2 increases proliferation of valve primordia mesenchymal cells via extracellular signal-regulated kinase 1/2 signaling. Circ Res 97: 813-820.

Kruithof BP, Krawitz SA, Gaussin V. 2007. Atrioventricular valve development during late embryonic and postnatal stages involves condensation and extracellular matrix remodeling. Dev Biol 302: 208-217.

Kruithof BP, Duim SN, Moerkamp AT, Goumans MJ. 2012. TGF- $\beta$ and BMP signaling in cardiac cushion formation: Lessons from mice and chicken. Differentiation 84: 89102.

$\mathrm{Ku}$ CH, Johnson PH, Batten P, Sarathchandra P, Chambers RC, Taylor PM, Yacoub MH, Chester AH. 2006. Collagen synthesis by mesenchymal stem cells and aortic valve interstitial cells in response to mechanical stretch. Cardiovasc Res 71: 548-556.

Lamers WH, Viragh S, Wessels A, Moorman AF, Anderson RH. 1995. Formation of the tricuspid valve in the human heart. Circulation 91: 111-121.

Lange AW, Yutzey KE. 2006. NFATc1 expression in the developing heart valves is responsive to the RANKL pathway and is required for endocardial expression of cathepsin K. Dev Biol 292: 407-417.

Latif N, Sarathchandra P, Taylor PM, Antoniw J, Yacoub MH. 2005. Localization and pattern of expression of extracellular matrix components in human heart valves. $J$ Heart Valve Dis 14: 218-227.

Latif N, Sarathchandra P, Thomas PS, Antoniw J, Batten P, Chester AH, Taylor PM, Yacoub MH. 2007. Characterization of structural and signaling molecules by human valve interstitial cells and comparison to human mesenchymal stem cells. J Heart Valve Dis 16: 56-66.
Leask RL, Jain N, Butany J. 2003. Endothelium and valvular diseases of the heart. Microsc Res Tech 60: 129-137.

Lencinas A, Tavares AL, Barnett JV, Runyan RB. 2011. Collagen gel analysis of epithelial-mesenchymal transition in the embryo heart: An in vitro model system for the analysis of tissue interaction, signal transduction, and environmental effects. Birth Defects Res C Embryo Today 93: 298-311.

Lepage L, Krapf L, Hekimian G, Duval X, Nataf P, Hvass U, Vahanian A, Messika-Zeitoun D. 2012. Unusual presentation of cryolife O'Brien stentless aortic valve bioprosthesis dysfunction mimicking infective endocarditis. Eur J Cardiothorac Surg 41: 800-805.

Levay AK, Peacock JD, Lu Y, Koch M, Hinton RB Jr, Kadler KE, Lincoln J. 2008. Scleraxis is required for cell lineage differentiation and extracellular matrix remodeling during murine heart valve formation in vivo. Circ Res 103: 948-956.

Leyh RG, Wilhelmi M, Rebe P, Fischer S, Kofidis T, Haverich A, Mertsching H. 2003. In vivo repopulation of xenogeneic and allogeneic acellular valve matrix conduits in the pulmonary circulation. Ann Thorac Surg 75: 1457-1463; discussion 1463

Lie-Venema H, van den Akker NM, Bax NA, Winter EM, Maas S, Kekarainen T, Hoeben RC, deRuiter MC, Poelmann RE, Gittenberger-de Groot AC. 2007. Origin, fate, and function of epicardium-derived cells (EPDCs) in normal and abnormal cardiac development. Scientific World Journal 7: 1777-1798.

Lim J, Thiery JP. 2012. Epithelial-mesenchymal transitions: Insights from development. Development 139: $3471-$ 3486 .

Lin CJ, Lin CY, Chen CH, Zhou B, Chang CP. 2012. Partitioning the heart: Mechanisms of cardiac septation and valve development. Development 139: 3277-3299.

Lincoln J, Alfieri CM, Yutzey KE. 2004. Development of heart valve leaflets and supporting apparatus in chicken and mouse embryos. Dev Dyn 230: 239-250.

Lincoln J, Alfieri CM, Yutzey KE. 2006a. BMP and FGF regulatory pathways control cell lineage diversification of heart valve precursor cells. Dev Biol 292: 292-302.

Lincoln J, Lange AW, Yutzey KE. 2006b. Hearts and bones: Shared regulatory mechanisms in heart valve, cartilage, tendon, and bone development. Dev Biol 294: 292-302.

Lincoln J, Kist R, Scherer G, Yutzey KE. 2007. Sox9 is required for precursor cell expansion and extracellular matrix organization during mouse heart valve development. Dev Biol 305: 120-132.

Liu AC, Gotlieb AI. 2007. Characterization of cell motility in single heart valve interstitial cells in vitro. Histol Histopathol 22: 873-882.

Lockhart M, Wirrig E, Phelps A, Wessels A. 2011. Extracellular matrix and heart development. Birth Defects Res A Clin Mol Teratol 91: 535-550.

Luna-Zurita L, Prados B, Grego-Bessa J, Luxan G, del Monte G, Benguria A, Adams RH, Perez-Pomares JM, de la Pompa JL. 2010. Integration of a Notch-dependent mesenchymal gene program and Bmp2-driven cell invasiveness regulates murine cardiac valve formation. J Clin Invest 120: $3493-3507$. 
D. MacGrogan et al.

Ma L, Lu MF, Schwartz RJ, Martin JF. 2005. Bmp2 is essential for cardiac cushion epithelial-mesenchymal transition and myocardial patterning. Development 132: 56015611.

Manner J. 2009. The anatomy of cardiac looping: A step towards the understanding of the morphogenesis of several forms of congenital cardiac malformations. Clin Anat 22: 21-35.

Maron BJ, Hutchins GM. 1974. The development of the semilunar valves in the human heart. Am J Pathol 74: 331-344.

Martin LJ, Ramachandran V, Cripe LH, Hinton RB, Andelfinger G, Tabangin M, Shooner K, Keddache M, Benson DW. 2007. Evidence in favor of linkage to human chromosomal regions $18 \mathrm{q}, 5 \mathrm{q}$ and $13 \mathrm{q}$ for bicuspid aortic valve and associated cardiovascular malformations. Hum Genet 121: 275-284.

Merryman WD, Youn I, Lukoff HD, Krueger PM, Guilak F, Hopkins RA, Sacks MS. 2006. Correlation between heart valve interstitial cell stiffness and transvalvular pressure: Implications for collagen biosynthesis. Am J Physiol Heart Circ Physiol 290: H224-H231.

Miller DV, Edwards WD, Zehr KJ. 2006. Endothelial and smooth muscle cell populations in a decellularized cryopreserved aortic homograft (SynerGraft) 2 years after implantation. J Thorac Cardiovasc Surg 132: 175-176.

Mirza A, Hyvelin JM, Rochefort GY, Lermusiaux P, Antier D, Awede B, Bonnet P, Domenech J, Eder V. 2008. Undifferentiated mesenchymal stem cells seeded on a vascular prosthesis contribute to the restoration of a physiologic vascular wall. J Vasc Surg 47: 1313-1321.

Mol A, Driessen NJ, Rutten MC, Hoerstrup SP, Bouten CV, Baaijens FP. 2005a. Tissue engineering of human heart valve leaflets: A novel bioreactor for a strain-based conditioning approach. Ann Biomed Eng 33: 1778-1788.

Mol A, van Lieshout MI, Dam-de Veen CG, Neuenschwander S, Hoerstrup SP, Baaijens FP, Bouten CV. 2005b. Fibrin as a cell carrier in cardiovascular tissue engineering applications. Biomaterials 26: 3113-3121.

Mol A, Rutten MC, Driessen NJ, Bouten CV, Zund G, Baaijens FP, Hoerstrup SP. 2006. Autologous human tissueengineered heart valves: Prospects for systemic application. Circulation 114: I152-I158.

Nakamura T, Colbert MC, Robbins J. 2006. Neural crest cells retain multipotential characteristics in the developing valves and label the cardiac conduction system. Circ Res 98: $1547-1554$.

Neidert MR, Tranquillo RT. 2006. Tissue-engineered valves with commissural alignment. Tissue Eng 12: 891-903.

Niessen K, Fu Y, Chang L, Hoodless PA, McFadden D, Karsan A. 2008. Slug is a direct Notch target required for initiation of cardiac cushion cellularization. J Cell Biol 182: $315-325$.

Norris RA, Moreno-Rodriguez RA, Sugi Y, Hoffman S, Amos J, Hart MM, Potts JD, Goodwin RL, Markwald RR. 2008. Periostin regulates atrioventricular valve maturation. Dev Biol 316: 200-213.

Norris RA, Moreno-Rodriguez R, Hoffman S, Markwald RR. 2009. The many facets of the matricelluar protein periostin during cardiac development, remodeling, and pathophysiology. J Cell Commun Signal 3: 275-286.
Peacock JD, Lu Y, Koch M, Kadler KE, Lincoln J. 2008. Temporal and spatial expression of collagens during murine atrioventricular heart valve development and maintenance. Dev Dyn 237: 3051-3058.

Person AD, Klewer SE, Runyan RB. 2005. Cell biology of cardiac cushion development. Int Rev Cytol 243:287-335.

Pittenger MF, Martin BJ. 2004. Mesenchymal stem cells and their potential as cardiac therapeutics. Circ Res 95: 9-20.

Poelmann RE, Gittenberger-de Groot AC. 2005. Apoptosis as an instrument in cardiovascular development. Birth Defects Res C Embryo Today 75: 305-313.

Prodromo J, D’Ancona G, Amaducci A, Pilato M. 2012. Aortic valve repair for aortic insufficiency: A review. $J$ Cardiothorac Vasc Anesth 26: 923-932.

Rabkin E, Aikawa M, Stone JR, Fukumoto Y, Libby P, Schoen FJ. 2001. Activated interstitial myofibroblasts express catabolic enzymes and mediate matrix remodeling in myxomatous heart valves. Circulation 104: 2525-2532.

Rabkin-Aikawa E, Farber M, Aikawa M, Schoen FJ. 2004. Dynamic and reversible changes of interstitial cell phenotype during remodeling of cardiac valves. J Heart Valve Dis 13: 841-847.

Ranger AM, Grusby MJ, Hodge MR, Gravallese EM, de la Brousse FC, Hoey T, Mickanin C, Baldwin HS, Glimcher LH. 1998. The transcription factor NF-ATc is essential for cardiac valve formation. Nature 392: 186-190.

Rieder E, Seebacher G, Kasimir MT, Eichmair E, Winter B, Dekan B, Wolner E, Simon P, Weigel G. 2005. Tissue engineering of heart valves: Decellularized porcine and human valve scaffolds differ importantly in residual potential to attract monocytic cells. Circulation 111: 2792-2797.

Riem Vis PW, Kluin J, Sluijter JP, van Herwerden LA, Bouten CV. 2011. Environmental regulation of valvulogenesis: Implications for tissue engineering. Eur J Cardiothorac Surg 39: 8-17.

Rivera-Feliciano J, Lee KH, Kong SW, Rajagopal S, Ma Q, Springer Z, Izumo S, Tabin CJ, Pu WT. 2006. Development of heart valves requires Gata4 expression in endothelial-derived cells. Development 133: 3607-3618.

Rodgers LS, Lalani S, Hardy KM, Xiang X, Broka D, Antin PB, Camenisch TD. 2006. Depolymerized hyaluronan induces vascular endothelial growth factor, a negative regulator of developmental epithelial-to-mesenchymal transformation. Circ Res 99: 583-589.

Roh JD, Sawh-Martinez R, Brennan MP, Jay SM, Devine L, Rao DA, Yi T, Mirensky TL, Nalbandian A, Udelsman B, et al. 2010. Tissue-engineered vascular grafts transform into mature blood vessels via an inflammation-mediated process of vascular remodeling. Proc Natl Acad Sci 107: 4669-4674.

Romano LA, Runyan RB. 1999. Slug is a mediator of epithelial-mesenchymal cell transformation in the developing chicken heart. Dev Biol 212: 243-254.

Rubbens MP, Driessen-Mol A, Boerboom RA, Koppert MM, van Assen HC, TerHaar Romeny BM, Baaijens FP, Bouten CV. 2009. Quantification of the temporal evolution of collagen orientation in mechanically conditioned engineered cardiovascular tissues. Ann Biomed Eng 37: $1263-1272$.

Ruffer A, Purbojo A, Cicha I, Glockler M, Potapov S, Dittrich S, Cesnjevar RA. 2010. Early failure of xenogenous 
de-cellularised pulmonary valve conduits-A word of caution! Eur J Cardiothorac Surg 38: 78-85.

Sacks MS, Yoganathan AP. 2007. Heart valve function: A biomechanical perspective. Philos Trans $R$ Soc Lond B Biol Sci 362: 1369-1391.

Sales VL, Engelmayr GC Jr, Johnson JA Jr, Gao J, Wang Y, Sacks MS, Mayer JE Jr. 2007. Protein precoating of elastomeric tissue-engineering scaffolds increased cellularity, enhanced extracellular matrix protein production, and differentially regulated the phenotypes of circulating endothelial progenitor cells. Circulation 116: I55-63.

Sales VL, Mettler BA, Engelmayr GC Jr, Aikawa E, Bischoff J, Martin DP, Exarhopoulos A, Moses MA, Schoen FJ, Sacks MS, et al. 2010. Endothelial progenitor cells as a sole source for ex vivo seeding of tissue-engineered heart valves. Tissue Eng Part A 16: 257-267.

Sanchez-Soria P, Camenisch TD. 2010. ErbB signaling in cardiac development and disease. Semin Cell Dev Biol 21: 929-935.

Sander EA, Barocas VH, Tranquillo RT. 2011. Initial fiber alignment pattern alters extracellular matrix synthesis in fibroblast-populated fibrin gel cruciforms and correlates with predicted tension. Ann Biomed Eng 39: 714-729.

Sayk F, Bos I, Schubert U, Wedel T, Sievers HH. 2005. Histopathologic findings in a novel decellularized pulmonary homograft: An autopsy study. Ann Thorac Surg 79: 1755-1758.

Scherz PJ, Huisken J, Sahai-Hernandez P, Stainier DYR. 2008. High-speed imaging of developing heart valves reveals interplay of morphogenesis and function. Development 135: 1179-1187.

Schmidt D, Achermann J, Odermatt B, Breymann C, Mol A, Genoni M, Zund G, Hoerstrup SP. 2007. Prenatally fabricated autologous human living heart valves based on amniotic fluid derived progenitor cells as single cell source. Circulation 116: I64-I70.

Schmidt D, Dijkman PE, Driessen-Mol A, Stenger R, Mariani C, Puolakka A, Rissanen M, Deichmann T, Odermatt B, Weber B, et al. 2010. Minimally invasive implantation of living tissue engineered heart valves: A comprehensive approach from autologous vascular cells to stem cells. J Am Coll Cardiol 56: 510-520.

Schoen FJ. 2008. Evolving concepts of cardiac valve dynamics: The continuum of development, functional structure, pathobiology, and tissue engineering. Circulation 118: $1864-1880$

Schoen FJ, Levy RJ. 2005. Calcification of tissue heart valve substitutes: Progress toward understanding and prevention. Ann Thorac Surg 79: 1072-1080.

Schroeder JA, Jackson LF, Lee DC, Camenisch TD. 2003. Form and function of developing heart valves: Coordination by extracellular matrix and growth factor signaling. J Mol Med (Berl) 81: 392-403.

Shelton EL, Yutzey KE. 2007. Tbx20 regulation of endocardial cushion cell proliferation and extracellular matrix gene expression. Dev Biol 302: 376-388.

Shinoka T, Breuer CK, Tanel RE, Zund G, Miura T, Ma PX, Langer R, Vacanti JP, Mayer JE Jr. 1995. Tissue engineering heart valves: Valve leaflet replacement study in a lamb model. Ann Thorac Surg 60: S513-S516.
Simmons CA, Grant GR, Manduchi E, Davies PF. 2005. Spatial heterogeneity of endothelial phenotypes correlates with side-specific vulnerability to calcification in normal porcine aortic valves. Circ Res 96: 792-799.

Simon P, Kasimir MT, Seebacher G, Weigel G, Ullrich R, Salzer-Muhar U, Rieder E, Wolner E. 2003. Early failure of the tissue engineered porcine heart valve SYNERGRAFT in pediatric patients. Eur J Cardiothorac Surg 23: 1002-1006; discussion 1006.

Singh MK, Christoffels VM, Dias JM, Trowe MO, Petry M, Schuster-Gossler K, Burger A, Ericson J, Kispert A. 2005. Tbx20 is essential for cardiac chamber differentiation and repression of Tbx2. Development 132: 2697-2707.

Siu SC, Silversides CK. 2010. Bicuspid aortic valve disease. J Am Coll Cardiol 55: 2789-2800.

Snarr BS, Kern CB, Wessels A. 2008. Origin and fate of cardiac mesenchyme. Dev Dyn 237: 2804-2819.

Snider P, Hinton RB, Moreno-Rodriguez RA, Wang J, Rogers R, Lindsley A, Li F, Ingram DA, Menick D, Field L, et al. 2008. Periostin is required for maturation and extracellular matrix stabilization of noncardiomyocyte lineages of the heart. Circ Res 102: 752-760.

Soini Y, Satta J, Maatta M, Autio-Harmainen H. 2001. Expression of MMP2, MMP9, MT1-MMP, TIMP1, and TIMP2 mRNA in valvular lesions of the heart. J Pathol 194: $225-231$.

Srivastava D. 2006. Making or breaking the heart: From lineage determination to morphogenesis. Cell 126: $1037-$ 1048.

Stankunas K, Ma GK, Kuhnert FJ, Kuo CJ, Chang CP. 2010. VEGF signaling has distinct spatiotemporal roles during heart valve development. Dev Biol 347: 325-336.

Stella JA, D'Amore A, Wagner WR, Sacks MS. 2010. On the biomechanical function of scaffolds for engineering loadbearing soft tissues. Acta Biomater 6: 2365-2381.

Stennard FA, Costa MW, Lai D, Biben C, Furtado MB, Solloway MJ, McCulley DJ, Leimena C, Preis JI, Dunwoodie SL, et al. 2005. Murine T-box transcription factor Tbx20 acts as a repressor during heart development, and is essential for adult heart integrity, function and adaptation. Development 132: 2451-2462.

Stephens EH, Post AD, Laucirica DR, Grande-Allen KJ. 2010. Perinatal changes in mitral and aortic valve structure and composition. Pediatr Dev Pathol 13: 447-458.

Sun Y, Liang X, Najafi N, Cass M, Lin L, Cai CL, Chen J, Evans SM. 2007. Islet 1 is expressed in distinct cardiovascular lineages, including pacemaker and coronary vascular cells. Dev Biol 304: 286-296.

Sutherland FW, Perry TE, Yu Y, Sherwood MC, Rabkin E, Masuda Y, Garcia GA, McLellan DL, Engelmayr GC Jr, Sacks MS, et al. 2005. From stem cells to viable autologous semilunar heart valve. Circulation 111: 2783-2791.

Syedain ZH, Weinberg JS, Tranquillo RT. 2008. Cyclic distension of fibrin-based tissue constructs: Evidence of adaptation during growth of engineered connective tissue. Proc Natl Acad Sci 105: 6537-6542.

Syedain ZH, Bradee AR, Kren S, Taylor DA, Tranquillo RT. 2013. Decellularized tissue-engineered heart valve leaflets with recellularization potential. Tissue Eng Part A 19: 759-769. 
D. MacGrogan et al.

Tan H, Junor L, Price RL, Norris RA, Potts JD, Goodwin RL. 2011. Expression and deposition of fibrous extracellular matrix proteins in cardiac valves during chick development. Microsc Microanal 17: 91-100.

Tao G, Kotick JD, Lincoln J. 2012. Heart valve development, maintenance, and disease: The role of endothelial cells. Curr Top Dev Biol 100: 203-232.

Taylor PM, Batten P, Brand NJ, Thomas PS, Yacoub MH. 2003. The cardiac valve interstitial cell. Int J Biochem Cell Biol 35: 113-118.

Timmerman LA, Grego-Bessa J, Raya A, Bertran E, Perez-Pomares JM, Diez J, Aranda S, Palomo S, McCormick F, Izpisua-Belmonte JC, et al. 2004. Notch promotes epithelialmesenchymal transition during cardiac development and oncogenic transformation. Genes Dev 18: 99-115.

Uccelli A, Moretta L, Pistoia V. 2006. Immunoregulatory function of mesenchymal stem cells. Eur J Immunol 36: 2566-2573.

van Vlimmeren MA, Driessen-Mol A, Oomens CW, Baaijens FP. 2012. Passive and active contributions to generated force and retraction in heart valve tissue engineering. Biomech Model Mechanobiol 11: 1015-1027.

Verzi MP, McCulley DJ, De Val S, Dodou E, Black BL. 2005. The right ventricle, outflow tract, and ventricular septum comprise a restricted expression domain within the secondary/anterior heart field. Dev Biol 287: 134-145.

Vincentelli A, Wautot F, Juthier F, Fouquet O, Corseaux D, Marechaux S, Le Tourneau T, Fabre O, Susen S, Van Belle $\mathrm{E}$, et al. 2007. In vivo autologous recellularization of a tissue-engineered heart valve: Are bone marrow mesenchymal stem cells the best candidates? J Thorac Cardiovasc Surg 134: 424-432.

von Gise A, Pu WT. 2012. Endocardial and epicardial epithelial to mesenchymal transitions in heart development and disease. Circ Res 110: 1628-1645.

Walsh EC, Stainier DYR. 2001. UDP-glucose dehydrogenase required for cardiac valve formation in zebrafish. Science 293: $1670-1673$.

Warnock JN, Nanduri B, Pregonero Gamez CA, Tang J, Koback D, Muir WM, Burgess SC. 2011. Gene profiling of aortic valve interstitial cells under elevated pressure conditions: Modulation of inflammatory gene networks. Int J Inflam 2011: 176412.

Weber B, Scherman J, Emmert MY, Gruenenfelder J, Verbeek R, Bracher M, Black M, Kortsmit J, Franz T, Schoenauer $\mathrm{R}$, et al. 2011. Injectable living marrow stromal cell-based autologous tissue engineered heart valves: First experiences with a one-step intervention in primates. Eur Heart J 32: 2830-2840.

Weber B, Emmert MY, Hoerstrup SP. 2012. Stem cells for heart valve regeneration. Swiss Med Wkly 142: w13622.

Weinberg EJ, Mack PJ, Schoen FJ, Garcia-Cardena G, Kaazempur Mofrad MR. 2010. Hemodynamic environments from opposing sides of human aortic valve leaflets evoke distinct endothelial phenotypes in vitro. Cardiovasc Eng 10: $5-11$.

Wessels A, Sedmera D. 2003. Developmental anatomy of the heart: A tale of mice and man. Physiol Genom 15: 165-176.

Wessels A, van den Hoff MJ, Adamo RF, Phelps AL, Lockhart MM, Sauls K, Briggs LE, Norris RA, van Wijk B, PerezPomares JM, et al. 2012. Epicardially derived fibroblasts preferentially contribute to the parietal leaflets of the atrioventricular valves in the murine heart. Dev Biol 366: $111-124$.

Weston MW, Yoganathan AP. 2001. Biosynthetic activity in heart valve leaflets in response to in vitro flow environments. Ann Biomed Eng 29: 752-763.

Wirrig EE, Hinton RB, Yutzey KE. 2011. Differential expression of cartilage and bone-related proteins in pediatric and adult diseased aortic valves. J Mol Cell Cardiol 50:561-569.

Wu B, Wang Y, Lui W, Langworthy M, Tompkins KL, Hatzopoulos AK, Baldwin HS, Zhou B. 2011. Nfatcl coordinates valve endocardial cell lineage development required for heart valve formation. Circ Res 109: 183-192.

Yacoub MH, Takkenberg JJ. 2005. Will heart valve tissue engineering change the world? Nat Clin Pract Cardiovasc Med 2: 60-61.

Yamada M, Revelli JP, Eichele G, Barron M, Schwartz RJ. 2000. Expression of chick Tbx-2, Tbx-3, and Tbx-5 genes during early heart development: Evidence for BMP2 induction of Tbx2. Dev Biol 228: 95-105.

Yamagishi T, Ando K, Nakamura H. 2009. Roles of TGF- $\beta$ and BMP during valvulo-septal endocardial cushion formation. Anat Sci Int 84: 77-87.

Yamanami M, Yahata Y, Uechi M, Fujiwara M, IshibashiUeda H, Kanda K, Watanabe T, Tajikawa T, Ohba K, Yaku H, et al. 2010. Development of a completely autologous valved conduit with the sinus of Valsalva using inbody tissue architecture technology: A pilot study in pulmonary valve replacement in a beagle model. Circulation 122: $\mathrm{S} 100-\mathrm{S} 106$.

Yang L, Cai CL, Lin L, Qyang Y, Chung C, Monteiro RM, Mummery CL, Fishman GI, Cogen A, Evans S. 2006. IsllCre reveals a common Bmp pathway in heart and limb development. Development 133: 1575-1585.

Ye Q, Zund G, Benedikt P, Jockenhoevel S, Hoerstrup SP, Sakyama S, Hubbell JA, Turina M. 2000. Fibrin gel as a three dimensional matrix in cardiovascular tissue engineering. Eur J Cardiothorac Surg 17: 587-591.

Yip CY, Chen JH, Zhao R, Simmons CA. 2009. Calcification by valve interstitial cells is regulated by the stiffness of the extracellular matrix. Arterioscler Thromb Vasc Biol 29: 936-942.

Yoganathan AP, Lemmon JD, Ellis JT. 2000. Heart valve dynamics. In The biomedical engineering handbook, $2 \mathrm{nd}$ ed. (ed. Bronzino JD). CRC, Boca Raton, FL.

Yutzey KE, Colbert M, Robbins J. 2005. Ras-related signaling pathways in valve development: Ebb and flow. Physiology (Bethesda) 20: 390-397.

Zaffran S, Kelly RG, Meilhac SM, Buckingham ME, Brown NA. 2004. Right ventricular myocardium derives from the anterior heart field. Circ Res 95: 261-268.

Zhao B, Etter L, Hinton RB Jr, Benson DW. 2007. BMP and FGF regulatory pathways in semilunar valve precursor cells. Dev Dyn 236: 971-980.

Zhou B, von Gise A, Ma Q, Hu YW, Pu WT. 2010. Genetic fate mapping demonstrates contribution of epicardiumderived cells to the annulus fibrosis of the mammalian heart. Dev Biol 338: 251-261.

Zilla P, Brink J, Human P, Bezuidenhout D. 2008. Prosthetic heart valves: Catering for the few. Biomaterials 29: 385406. 


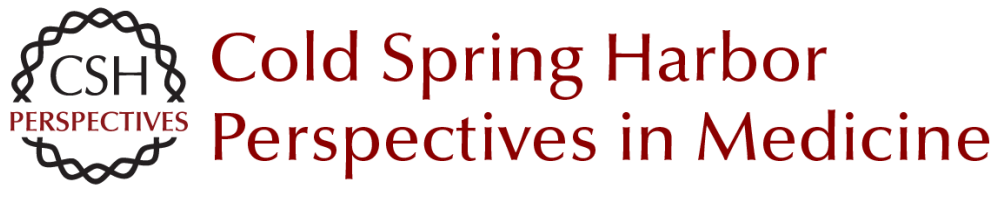

\section{How to Make a Heart Valve: From Embryonic Development to Bioengineering of Living Valve Substitutes}

Donal MacGrogan, Guillermo Luxán, Anita Driessen-Mol, Carlijn Bouten, Frank Baaijens and José Luis de la Pompa

Cold Spring Harb Perspect Med 2014; doi: 10.1101/cshperspect.a013912

Subject Collection The Biology of Heart Disease

The Genetic Basis of Aortic Aneurysm

Mark E. Lindsay and Harry C. Dietz

Personalized Genomes and Cardiovascular
Disease
Kiran Musunuru

Complex Genetics and the Etiology of Human

Congenital Heart Disease

Bruce D. Gelb and Wendy K. Chung

Genetic Networks Governing Heart Development Ashley J. Waardenberg, Mirana Ramialison, Romaric Bouveret, et al.

Heart Fields and Cardiac Morphogenesis Robert G. Kelly, Margaret E. Buckingham and Antoon F. Moorman

Regenerative Medicine: Transforming the Drug Discovery and Development Paradigm Sotirios K. Karathanasis

Myocardial Tissue Engineering: In Vitro Models Gordana Vunjak Novakovic, Thomas Eschenhagen and Christine Mummery

Pluripotent Stem Cell Models of Human Heart

Disease

Alessandra Moretti, Karl-Ludwig Laugwitz, Tatjana Dorn, et al.
Cardiac Cell Lineages that Form the Heart Sigolène M. Meilhac, Fabienne Lescroart, Cédric Blanpain, et al.

Synthetic Chemically Modified mRNA (modRNA):

Toward a New Technology Platform for

Cardiovascular Biology and Medicine Kenneth R. Chien, Lior Zangi and Kathy O. Lui

Next-Generation Models of Human Cardiogenesis via Genome Editing Xiaojun Lian, Jiejia Xu, Jinsong Li, et al.

How to Make a Heart Valve: From Embryonic Development to Bioengineering of Living Valve Substitutes

Donal MacGrogan, Guillermo Luxán, Anita Driessen-Mol, et al.

Insights into the Genetic Structure of Congenital Heart Disease from Human and Murine Studies on Monogenic Disorders

Terence Prendiville, Patrick Y. Jay and William T. $\mathrm{Pu}$

Cardiovascular Drug Discovery: A Perspective from a Research-Based Pharmaceutical Company G. Gromo, J. Mann and J.D. Fitzgerald

Genetics and Disease of Ventricular Muscle Diane Fatkin, Christine E. Seidman and Jonathan G. Seidman

Embryonic Heart Progenitors and Cardiogenesis Thomas Brade, Luna S. Pane, Alessandra Moretti, et al.

For additional articles in this collection, see http://perspectivesinmedicine.cshlp.org/cgi/collection/ 